2011

\title{
The "Reshapement of the False Negative Asymmetry in Toxic Tort Causation
}

Steve C. Gold

Follow this and additional works at: http://open.mitchellhamline.edu/wmlr

\section{Recommended Citation}

Gold, Steve C. (2011) "The "Reshapement" of the False Negative Asymmetry in Toxic Tort Causation," William Mitchell Law Review: Vol. 37: Iss. 3, Article 6.

Available at: http://open.mitchellhamline.edu/wmlr/vol37/iss3/6

This Article is brought to you for free and open access by the Law Reviews and Journals at Mitchell Hamline Open Access. It has been accepted for inclusion in William Mitchell Law Review by an authorized administrator of Mitchell Hamline Open Access. For more information, please contact sean.felhofer@mitchellhamline.edu.

(C) Mitchell Hamline School of Law

\section{$\mathrm{MH}$}

MITCHELL | HAMLINE OPEN ACCESS stoded the mitchellhamline.edu 


\title{
THE "RESHAPEMENT" OF THE FALSE NEGATIVE ASYMMETRY IN TOXIC TORT CAUSATION
}

\author{
By Steve C. Gold ${ }^{\dagger}$
}

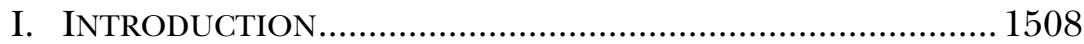

II. ThE JUdiCIAL PREFERENCE FOR FALSE NEgATIVES IN TOXIC TORT CAUSATION.

A. Judicial Treatment of General and Specific Causation.

B. Judicial Treatment of Epidemiology...

III. Why DOES THE FALSE NEGATIVE ASYMMETRY EXIST, AND IS IT JUSTIFIED?

A. The Science Rationale: Courts as Serfs of Statistics.... 1536

B. The Legitimacy Rationale: Courts in Need of Respect. 1542

C. The Welfare Rationale: Courts as Policy Makers

IV. COMMENT C: RESHAPING TOWARD SYMMETRY .................... 1560

A. General Causation and Specific Causation....................... 1563

B. Epidemiologic Evidence and Relative Risk Thresholds ........ 1566

1. Is Epidemiology Mandatory? ..................................... 1566

2. Must Relative Risk Exceed Two? ................................. 1567

C. The Role of Scientific Judgment and Inference.................... 1570

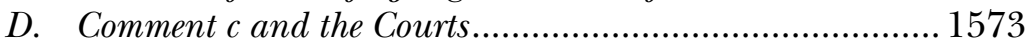

1. Ranes v. Adams Laboratories, Inc............................. 1573

2. Milward v. Acuity Specialty Products Group, Inc........ 1576

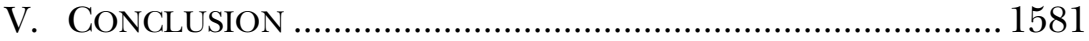

$\dagger \quad$ Associate Professor of Law, Rutgers School of Law-Newark. I owe thanks to Stuart Deutsch, Michael Green, and Andrew Klein for reviewing earlier drafts, to participants at the Symposium on the Third Restatement of Torts held at Wake Forest University School of Law in 2009, to the staff of the William Mitchell Law Review, to research assistants Karina Levitian and Brian Matthews, to the librarians at the Rutgers Law Library, and to my patient and supportive wife, Jennifer Aley. 


\section{INTRODUCTION}

To err is human. But we humans decidedly dislike error in legal fact-finding, even though we know it occurs. ${ }^{1}$ Confidence in and respect for the law as a method for dispute resolution depends on participants having a substantial degree of faith in the accuracy of legal fact-finding. Therefore, "getting it right" as often as possible is one key objective that informs the design of our legal system, its procedures, and its rules. ${ }^{2}$

The law does not claim infallibility, of course. Its standards of proof are not absolute. Nor does law necessarily treat all errors equally. The requirement of proof beyond a reasonable doubt in criminal cases evinces a strong preference for mistaken acquittal over mistaken conviction. ${ }^{3}$ The clear and convincing standard applied in some civil cases reflects a weaker but definite view that in those cases, an erroneous affirmative finding of the proposition advocated is worse than an erroneous rejection of the proposition. ${ }^{4}$ By contrast, the preponderance of the evidence standard of persuasion applied in most civil cases reflects, in principle, neutrality between incorrect impositions of liability and incorrect

1. See Brandon L. Garrett, The Substance of False Confessions, 62 STAN. L. REV. 1051, 1052 (2010) ("[P] ostconviction DNA has exonerated 252 convicts, forty-two of whom falsely confessed to rapes and murders.").

2. Russell Brown, The Possibility of "Inference Causation": Inferring Cause-in-Fact and the Nature of Legal Fact-Finding, 55 MCGILL L.J. 1, 14 (2010) ("[T] ruth-seeking is an elemental aspiration of our legal order."); Andrew R. Klein, Causation and Uncertainty: Making Connections in a Time of Change, 49 JURIMETRICS J. 5,8 (2008) ("[L] aw and uncertainty will remain intertwined, but the quest for getting it right should continue unabated"); Vern R. Walker, Preponderance, Probability and Warranted Factfinding, 62 BROOK. L. REV. 1075, 1081 (1996) ("[I]deal of legal factfinding ... entails attaining truth.”).

3. See, e.g., Alexander Volokh, n Guilty Men, 146 U. PA. L. Rev. 173 (1997) (discussing origins, applications and variations of the maxim "[b]etter that ten guilty persons escape, than that one innocent suffer").

4. See, e.g., Colorado v. New Mexico, 467 U.S. 310, 316-17 (1984) (holding that error allocation principles warrant imposing a clear-and-convincing standard on a state seeking diversion of previously appropriated water, because the harm to the party losing water is usually certain and immediate while the benefits to the party diverting water may be speculative and remote); Christopher $M$. Pietruszkiewicz, Conflating Standards of Review in the Tax Court: A Lesson in Ambiguity, 44 Hous. L. REv. 1337, 1366 n.167 (2008) (identifying patent infringement, involuntary commitment, parental rights termination, deportation, and denaturalization as types of cases in which clear and convincing evidence is required because they "involve more than the loss of money and concern important individual interests"). 
refusals to impose liability, ${ }^{5}$ except in the rare case of evidence in perfect equipoise, when it breaks the tie in favor of the defense. ${ }^{6}$

When causation is at issue in toxic tort claims, however, this theory has not aligned well with judicial practice. Such cases may present genuine scientific uncertainty, in which there is reason to suspect a disease-exposure link and reason to doubt it. Each case must be resolved, but any resolution risks error. Causation might be found although the asserted causal link is or later proves to be non-existent: a false positive. Or causation might not be found even though the asserted causal link is or later proves to be true: a false negative.

5. Restatement (ThiRd) OF TORTs: Liab. FOR Physical \& EMOTIONAl HaRm § $28 \mathrm{cmt}$. e reporters' note (2010) ("The law has already decided that, while it attempts to minimize errors, for those that do occur the law treats as equally costly errors favoring plaintiffs or defendants in civil cases and adopted a preponderance standard that reflects that determination."); see Herman \& MacLean v. Huddleston, 459 U.S. 375, 390 (1983) (explaining that a preponderance standard requires both sides to share the risk of error roughly equally, while "[a]ny other standard expresses a preference for one side's interests"). Some have questioned whether the preponderance standard should operate this way. See, e.g., Howard v. Wal-Mart Stores, Inc., 160 F.3d 358, 359-60 (7th Cir. 1998) ("Judges, and commentators on the law of evidence, have been troubled by cases in which the plaintiff has established a probability that only minutely exceeds [fifty]-percent that his version of what happened is correct" because of the transaction costs of adjudication). Others have doubted that the preponderance standard as applied actually achieves an equal distribution of the risk of error. See Walker, supra note 2, at 1099-1109 (criticizing claim that preponderance standard, understood as probability greater than 0.5 , produces equal numbers of errors in favor of plaintiffs and defendants); $i d$. at 1119-20 (arguing that unbiased treatment of parties, distinct from equal error distribution, still requires "a mid-range decision value").

6. This is true, of course, only of matters deemed "elements" of the plaintiff's case. For affirmative defenses on which the defendant bears the burden of proof, the tie-breaker favors plaintiff.

7. See David L. Faigman, Judges as "Amateur Scientists," 86 B.U. L. REv. 1207, 1212-14 (2006) (describing false positive and negative legal errors and illustrating that each of these errors may have distinctive costs). Scientists also distinguish between false positives and false negatives. Scientific research often compares some attribute of two samples to determine whether the attribute differs between the populations being sampled. The assumption that no difference exists is called the null hypothesis. David H. Kaye \& David A. Freedman, Reference Guide on Statistics, in Reference Manual on Scientific Evidence 83, 167 (Fed. Judicial Ctr. ed., 2d ed. 2000). Statisticians conventionally divide sampling error into "Type I" error, which occurs when sampling error creates the illusion of a difference even though the populations' parametric values are the same, and "Type II" error, which occurs when the sample measurements fail to detect a real difference between the parametric values. Id. at 176. Type I and Type II errors can be characterized as "false negatives" and "false positives," respectively. Id. To avoid any implication that the potential errors in legal fact-finding discussed herein are 
In these circumstances, many courts do not behave as though the two types of error carry equal costs. Instead, using substantive requirements as well as evidentiary rules with dispositive effect, these courts demonstrate a preference for tolerating false negative findings on causation rather than risk false positive findings, creating a "false negative asymmetry" in toxic tort causation law.

Part II of this article argues that a widespread preference for false negatives on toxic tort causation can be inferred from the case law. ${ }^{8}$ Part III examines several possible sources of the false negative asymmetry and assesses their explanatory and normative persuasiveness. ${ }^{9}$ Part IV evaluates the extended treatment of toxic tort causation in the Restatement (Third) of Torts: Liability for Physical and Emotional Harm (2010) (Third Restatement) ${ }^{10}$ and concludes that the Third Restatement ${ }^{11}$ undermines the claim that the legal rules that produce the false negative asymmetry are mere enhancements to judicial truth-seeking. ${ }^{2}$ Therefore, if the Third Restatement is properly understood and applied by courts, it could reshape toward symmetry the currently asymmetrical law of toxic tort causation.

\section{The JUdicial PREFERENCE FOR FALSE NEGATIVES IN TOXIC TORT CAUSATION}

Scientific uncertainty of a type not usually seen in other tort cases poses recognized, unique obstacles to proof of toxic tort causation. ${ }^{13}$ Although some commentators have argued that these obstacles justify various proposals to relax the burden of proof, ${ }^{14}$

congruent with the statistical concepts, this Article uses "Type I" and "Type II" only in their statistical sense.

8. See infra Part II. This is not intended to suggest that case law is uniform or that all jurisdictions or all courts have applied the false negative asymmetry.

9. See infra Part III. This analysis focuses on the decision rules that create the asymmetry rather than the correctness of the outcome in individual cases, including the cases in which those rules were articulated.

10. Restatement (Third) OF TORTS: Liab. FOR Physical \& EMOTIONAl Harm $\S$ $28 \mathrm{cmt}$. c, cmt. c reporters' note $(2010)$.

11. Unless otherwise made clear, "Third Restatement" herein refers generally to the Restatement (Third) of Torts: Liab. for Physical \& Emotional Harm.

12. See infra Part IV.

13. Conde v. Velsicol Chem. Corp., 804 F. Supp. 972, 995 (S.D. Ohio 1992) ("In toxic tort cases, the Court must be aware of "the difficulty of scientists and hence of judges, lawyers, and jurors in knowing what reasonable inferences of causation to draw ...." (citation omitted)); RESTATEMENT (THIRD) OF TORTS: LIAB. FOR PHYSiCAL \& EMOTIONAL HARM $§ 28 \mathrm{cmt}$. c (2010).

14. Margaret A. Berger, Eliminating General Causation: Notes Towards a New 
courts for the most part continue to insist that toxic tort plaintiffs establish causation in the traditional counterfactual way: proving that, more likely than not, a plaintiff's illness or injury would not have occurred but for a defendant's tortious conduct.

But to say that a plaintiff must prove but-for causation by a preponderance of the evidence is to begin rather than to end the inquiry, for the next question is what a plaintiff must accomplish to satisfy that burden. To give content to the factual causation element of a toxic tort claim, judges must make legal decisions about what evidence will be considered probative and what evidence will be considered sufficient (at least to create a triable issue). These choices, on a series of issues relating to both admissibility and sufficiency of evidence, reveal that many courts believe it is better to risk rejecting a plaintiff's claim of causation that (while uncertain) might be true than to risk finding a defendant liable based on a claim of causation that (while uncertain) might be untrue.

\section{A. Judicial Treatment of General and Specific Causation}

After a traumatic accident, fact-finders quite willingly infer causation from the simple temporal sequence that a plaintiff was uninjured before the accident and was suffering from harm afterward. ${ }^{16}$ Courts rarely allow similar inference in toxic injury

Theory of Justice and Toxic Torts, 97 CoLuM. L. REV. 2117 (1997) (arguing that not requiring proof of general causation would enhance tort law's corrective justice function); Thomas O. McGarity, Proposal for Linking Culpability and Causation to Ensure Corporate Accountability for Toxic Risks, 26 WM. \& MARY ENVTL. L. \& POL'Y REV. 1 (2001) (proposing an administrative and legislative approach using presumptions to link causation to culpability); David Rosenberg, The Causal Connection in Mass Exposure Cases: A 'Public Law'Vision of the Tort System, 97 HaRv. L. REV. 849 (1984) (arguing that proportional recovery would improve tort law's efficiency performance).

15. See, e.g., June v. Union Carbide Corp., 577 F.3d 1234, 1244 (10th Cir. 2009). The major exception has occurred where the causal link between a substance and a disease was relatively clear, and the principal problem was identifying the manufacturer or supplier of the particular disease-causing product. See, e.g., Rutherford v. Owens-Ill., Inc., 941 P.2d 1203, 1219-20 (Cal. 1997) (holding that in light of "irreducible uncertainty" of determining which defendants' asbestos fibers actually contributed to cellular development of cancer, each product would be "a substantial factor in causing . . . the disease if . . . it was a substantial factor contributing to ... [the] risk of developing cancer"); Hymowitz v. Eli Lilly \& Co., 539 N.E.2d 1069, 1078 (N.Y. 1989) (approving market share liability in DES cases where injured daughters could not identify manufacturer of pill ingested by their mothers).

16. Restatement (Third) of Torts: Liab. for Physical \& Emotional Harm § 
cases, because of the invisible mechanism and delayed effect of toxic exposures, as well as the existence (except for "signature diseases" ${ }^{17}$ ) of other potentially sufficient causes of the harm suffered. $^{18}$ Instead, courts often have required toxic tort plaintiffs to prove both "general causation"-that the accused exposure is capable of causing the plaintiff's illness in at least some people-and "specific causation"- that the particular plaintiff's illness is an instance of the general causation possibility. ${ }^{19}$ These concepts lurk, as a philosophical matter, in almost any causal inquiry, ${ }^{20}$ but their express invocation is virtually unique to toxic torts. ${ }^{21}$

28 (2010).

17. For a signature disease, exposure to a particular substance seems to account for virtually all known cases of the illness. See, e.g., Norfolk \& W. Ry. Co. v. Ayers, 538 U.S. 135, 142 n.4 (2003) ("Asbestos is the only cause of mesothelioma established thus far, although some instances of the disease are not traceable to asbestos."); see also Leslie Bender, An Overview of Feminist Torts Scholarship, 78 CORNELl L. REV. 575, 587 n.52 (identifying cervical and vaginal clear cell adenoma as signatures of in utero exposure to DES).

18. See, e.g., Michael D. Green, The Future of Proportional Liability: The Lessons of Toxic Substances Causation, in EXPLORING TORT LAW 352, 372-73 (M. Stuart Madden ed., 2005) (explaining causation difficulties in toxic tort cases).

19. See, e.g., In re Baycol Prods. Litig., 596 F.3d 884, 889 (8th Cir. 2010) (noting that although plaintiff's experts could testify as to general causation, "the issue on appeal is specific causation"); Henricksen v. ConocoPhillips Co., 605 F. Supp. 2d 1142, 1176 (E.D. Wash. 2009) (noting that plaintiff must prove both general and specific causation although the "court's ultimate focus" is proof that exposure caused the individual plaintiff's disease).

20. Joseph Sanders, The Controversial Comment c: Factual Causation in Toxic-substance and Disease Cases, 44 WAKE Forest L. REv. 1029, 1034 n.19 (2009); see generally RESTATEMENT (THIRD) OF TORTS: LIAB. FOR PHYSICAL \& EMOTIONAL HARM § 28 cmt. c reporters' note (2010) (citing Joseph Sanders \& Julie Machal-Fulks, The Admissibility of Differential Diagnosis Testimony to Prove Causation in Toxic Tort Cases: The Interplay of Adjective and Substantive Law, 64 LAW \& CONTEMP. Probs. 107, 110 n.13 (2001)).

21. A few courts have borrowed these concepts and applied them to other types of cases in which the fact-finder could not readily infer causation from common experience. For example, in a case involving a house fire allegedly caused by a defective clothes dryer, the court described the general causation issue as whether restricted airflow could cause lint buildup in dryers and specific causation as whether this occurred in the particular dryer in question. Automobile Ins. Co. of Hartford v. Electrolux Home Prods., Inc., No. 08-CV00623(A) (M), 2010 U.S. Dist. LEXIS 96153, at*13-14 (W.D.N.Y. Sept. 15, 2010) (citing Amorgianos v. Nat'l R. Passenger Corp., 303 F.3d 256, 268 (2d Cir. 2002), a toxic tort case in which plaintiff alleged paint fumes caused nervous system damage) (excluding defense expert's testimony on specific causation for failure to rule out other causes). 
The sharp distinction was originally urged by plaintiffs' lawyers seeking the leverage of class treatment in mass exposure cases, who argued that general causation was a common issue meriting classwide adjudication even if each plaintiff's claim of specific causation required individual resolution. ${ }^{22}$ The distinction invited courts to consider independently what evidence would support reasonable inferences, as opposed to impermissible speculation, of general and specific causation. To the extent courts treat general and specific causation as separate elements requiring distinct proof, plaintiffs who already confront scientific uncertainty may be required to jump two hurdles instead of one-increasing the likelihood of false negative adjudications on causation.

Casey v. Ohio Medical Products ${ }^{23}$ illustrates the thought process. Defendant moved to exclude plaintiff's proffered expert testimony that halothane ${ }^{24}$ caused plaintiff's chronic hepatitis. "The term

22. Joseph Sanders traced judicial use of these terms to an opinion in the Agent Orange litigation. Sanders, supra note 20, at 1030 n.5 (citing In re Agent Orange Prod. Liab. Litig., 570 F. Supp. 693, 695 (E.D.N.Y. 1983)). The Judicial Panel on Multidistrict Litigation had earlier concluded that the "characteristics" of Agent Orange, "including its allegedly toxic nature," presented factual issues common to multiple cases. In re Agent Orange Prod. Liab. Litig., No. M.D.L. 381, 1980 U.S. Dist. LEXIS 9945, at *5-6 (J.P.M.L. Jan. 29, 1980). The district judge assigned to the transferred multidistrict litigation quickly recognized that "there is a major dispute over whether Agent Orange can cause the injuries in question, and there are separate disputes over whether the exposure claimed in each case did cause the injuries claimed." In re Agent Orange Prod. Liab. Litig., 506 F. Supp. 762, 783 (E.D.N.Y. 1980) (emphasis added). Therefore, class treatment made sense for "the many questions embodied in the concept of 'general causation," even though "issues of specific causation and damages will . . . ultimately require individual consideration." Id. at 787-88; see also In re Diamond Shamrock Chems. Co., 725 F.2d 858 (2d Cir. 1984); In re "Agent Orange" Prod. Liab. Litig., 100 F.R.D. 718, 722-24 (E.D.N.Y. 1983) (formally certifying class action in part because general causation was common issue), mandamus denied. But see, e.g., In re Tetracycline Cases, 107 F.R.D. 719, 733 (W.D. Mo. 1985) (rejecting plaintiff's argument that general causation was common issue justifying class certification). In another early use of these terms, some courts and commentators used "general causation" to refer to the link between a particular material (e.g. asbestos) and a disease, and used "specific causation" to refer to the link between a particular defendant's product containing that material and a particular plaintiff's disease. See, e.g., Menne v. Celotex Corp., 641 F. Supp. 1429, 1436 (D. Kan. 1986); Richard Delgado, Beyond Sindell: Relaxation of Cause-in-Fact Rules for Indeterminate Plaintiffs, 70 CALIF. L. REV. 881, 882 n.8 (1982).

23. 877 F. Supp. 1380 (N.D. Cal. 1995).

24. Halothane is a halogenated hydrocarbon used as an anesthetic. U.S. DePT. OF LABOR, OCCUPATIONAL SAFETy \& HeAlth Guideline For Halothane, http://63.234.227.130/SLTC/healthguidelines/halothane/recognition.html (last visited Jan. 24, 2011). 
'causation' has two meanings here," the court explained, ${ }^{25}$ and the evidence in support of each "meaning" of causation must be examined separately. ${ }^{26} \quad$ Persuaded by defendant's expert's testimony that "there has never been a reported case or an epidemiological study plausibly linking halothane to chronic active hepatitis," the court ruled that plaintiff's proffered expert testimony on general causation was unreliable and inadmissible. ${ }^{27}$

With that, the court might have dispensed with discussion of specific causation, but it chose to address specific causation "because specific causation is a vital step in the required chain of legal causation .....28 The court held that plaintiff's proffered expert testimony on specific causation, too, was both inadmissible and insufficient. ${ }^{29}$ In doing so, the court offered a glimpse of what it would require as evidence of specific causation:

Plaintiff again relies upon Dr. Harrison to establish specific causation. Dr. Harrison does so in paragraphs of his declaration in which he analyzes the information known about the progress of plaintiff's disease and plaintiff's possible pre-existing conditions. However, direct evidence is scant-not because of any lack of diligence on Dr. Harrison's part, but because of the limited information available about plaintiff's pathology and the lengthy fifteen year period of his decline. With scant direct evidence, Dr. Harrison's opinion about "did" must rely heavily upon this opinion about "can.,"

The key is the court's desire for "direct" evidence, whatever that might be. This demand is akin to a requirement of "particularistic" evidence on specific causation, ${ }^{31}$ in contrast to (and

25. 877 F. Supp. at 1382 (citing Daubert v. Merrell Dow Pharms., 43 F.3d 1311, 1315 (9th Cir. 1995)).

26. Id. at 1383 (noting that plaintiff's expert testimony "must include both general causation (can halothane cause chronic active hepatitis) and specific causation (did plaintiff's exposure to halothane cause his chronic active hepatitis)").

27. Id. at 1384-86.

28. Id. at 1386; see also Dunn v. Sandoz Pharms. Corp., 275 F. Supp. 2d 672, 676 (M.D.N.C. 2003) (noting that, because the court excluded plaintiff's expert testimony on general causation, "it is unnecessary to consider" experts who would testify on specific causation).

29. Casey, 877 F. Supp. at 1386.

30. Id.

31. See Joseph Sanders, Apportionment and Proof in Toxic Injury Cases, $10 \mathrm{KaN}$. J.L. \& PUB. POL'Y 200, 202 (2000) (noting that particularistic evidence has been the "holy grail" of toxic tort cases). 
in addition to) an insistence on group-based epidemiologic evidence on general causation. ${ }^{32}$ Much judicial analysis of specific causation betrays continued uneasiness with cases that lack such individualized proof. For example, in Henricksen v. ConocoPhillips Co., ${ }^{33}$ the court rejected plaintiff's attempt to prove specific causation in the face of defense testimony that most cases of plaintiff's disease were idiopathic: ${ }^{34}$

[T] he only reason cited for distinguishing Henricksen's disease from one of "no known cause" was the existence of a known risk factor, namely exposure to benzene. Standing alone, the presence of a known risk factor is not a sufficient basis for ruling out idiopathic origin in a particular case.... [Plaintiff's expert] could have compared the presentation of Henricksen's symptoms with those in chemically induced AML cases ... . None of the features characteristic or commonly seen in secondary AML have been associated with Henricksen's case. ${ }^{35}$

The lack of some kind of corroborative particularistic evidence has been important in other cases as well. ${ }^{36}$ Alternatively, some courts have said that to "satisfy specific causation, plaintiff's expert witnesses were required to exclude all other possible causes" of plaintiff's condition, ${ }^{37}$ an impossible demand. ${ }^{38}$ Courts that use less

32. The court's exclusion of plaintiff's expert's opinion on general causation relied heavily on the absence of epidemiologic evidence. Casey, 877 F. Supp. at 1384-85.

33. 605 F. Supp.2d 1142 (E.D. Wash. 2009).

34. The court appeared to equate idiopathic cases ("with no readily identifiable cause") with "endogenous" cases ("onset without external or environmental stimulus"). Id. at 1149.

35. Id. at 1162-63.

36. See, e.g., Tamraz v. Lincoln Elec. Co., 620 F.3d 665, 671 (6th Cir. 2010) (noting that plaintiff's expert could not describe any tests he had done "to tell the difference between a welder with idiopathic Parkinson's disease and a welder . . tipped into the Parkinson's disease by welding”); Cord v. City of Los Angeles, No. B167756, 2004 Cal. App. Unpub. LEXIS 8967, at *5 (2d Dist. Sept. 30, 2004) (noting defense expert's testimony that because plaintiffs did not test for biomarkers of exposure, "it is impossible to determine to a medical certainty" whether decedent had been exposed to a potentially carcinogenic dose); see also Tompkin v. Philip Morris USA, Inc., 362 F.3d 882, 890 n.5, 894 (6th Cir. 2004) (describing "devastating" trial testimony by defense expert that decedent's cancerous tissue lacked histological and genetic changes caused by tobacco smoke).

37. Wade-Greaux v. Whitehall Labs., Inc., 874 F. Supp. 1441, 1473 (D.V.I. 1994) (emphasis added).

38. See Heller v. Shaw Inds., Inc., 167 F.3d 146, 156 (3d Cir. 1999) (holding that district court erred in requiring expert to rule out all alternative possible 
absolute language nevertheless often impose very high burdens for ruling out other possible causes.

These holdings do not merely restate the traditional causation burden. They define that burden by deciding when inferences will be permitted in the face of incomplete scientific understanding. ${ }^{40}$ Despite disclaimers, ${ }^{41}$ holdings like these make it nearly impossible for a plaintiff to succeed if a significant proportion of the incidence of a disease is unexplained, because there is no way to exclude the unknown. $^{42}$

Such rulings, though they may seem justified if unknown causes account for eighty or ninety percent of the incidence of plaintiff's disease, ${ }^{43}$ quite consciously impose on plaintiffs the burden of ignorance. ${ }^{4}$ The ignorance at issue, moreover, is not ignorance of the alleged causal link between plaintiff's exposure and plaintiff's illness, but of the causes of plaintiff's illness in general. $^{45}$ Over time, that ignorance may gradually yield to

causes); Stubbs v. City of Rochester, 124 N.E. 137, 140 (N.Y. 1919) (noting that ruling out all potential sources of plaintiff's typhoid would be impossible, and refusing to require plaintiff "to eliminate sources [of plaintiff's disease] which had not yet been determined or ascertained").

39. See, e.g., Soldo v. Sandoz Pharms. Corp., 244 F. Supp. 2d 434, 551-52 (W.D. Pa. 2003) (holding, while purportedly following Heller, that plaintiff must "reliably rule out" any alternative cause that defendant shows is "plausible"); Merrell Dow Pharms., Inc. v. Havner, 953 S.W.2d 706, 720 (Tex. 1997) (stating that even if reliable epidemiologic evidence shows that exposure more than doubled risk, "if there are other plausible causes . . . that could be negated, the plaintiff must offer evidence excluding those causes with reasonable certainty"); $c f$. Henricksen v. Conoco Phillips Co., 605 F. Supp. 2d 1142, 1162 (E.D. Wash. 2009) (noting that to be admissible, "expert testimony need not rule out all alternative causes" but excluding testimony for failure to rule out alternative cause of "no known cause").

40. See, e.g., Henricksen, 605 F. Supp. 2d at 1168.

41. See, e.g., id. at 1162 ("This is not to say that where most diagnoses of a disease are idiopathic it is impossible to prove specific causation.").

42. Wade-Greaux, 874 F. Supp. at 1485 (noting that plaintiff's experts "either have not excluded or cannot exclude," among other things, "those unknown events that cause the great majority of birth defects.").

43. Restatement (ThiRd) OF TORTs: Liab. FOR Physical \& EMOtional Harm § $28 \mathrm{cmt}$. c (2010) ("When the causes of a disease are largely unknown, however, differential etiology is of little assistance."); see also Henricksen, 605 F. Supp. 2d at 1149 (accepting as fact that eighty to ninety percent of all cases of plaintiff's illness are of idiopathic origin).

44. See Wendy E. Wagner, Choosing Ignorance in the Manufacture of Toxic Products, 82 CoRnell L. Rev. 773, 775, 792-93 (1997).

45. See, e.g., Tamraz v. Lincoln Elec. Co., 620 F.3d 665, 668 (6th Cir. 2010) ("The causes of Parkinson's Disease range from the obscure to the unknown."). 
knowledge. ${ }^{46}$ While science strives toward the perhaps unattainable goal of identifying every cause of a plaintiff's disease, the percentage of cases attributed to unknown etiology will decline. At what point is the residuum of unexplained disease small enough for a court to conclude that an expert could rule out enough alternative causes to be allowed to testify? To draw that line is to define the set of cases in which even plaintiffs exposed to known risk factors, rather than the defendants who do the exposing, bear the cost of gaps in knowledge.

Ironically, the problem of unknown etiology inverts the original dichotomy of general-versus-specific causation, in which courts questioned whether group-based epidemiology could speak to the cause of an individual plaintiff's condition. ${ }^{47}$ Courts that demand particularistic proof rely on a group-based characteristic, a significant proportion of idiopathic cases, to support the inference that the plaintiff has failed to introduce admissible and sufficient proof of causation in an individual case. ${ }^{48}$

Such reasoning may be valid-or not. Consider, for example, the relation between asbestos and mesothelioma, frequently described as a "signature" disease. ${ }^{49}$ Among persons not exposed to asbestos, mesothelioma is vanishingly rare. ${ }^{50}$ As a consequence, the relative risk for those exposed-the ratio of the incidence of disease in the exposed population to its incidence in the unexposed population-is extremely high. ${ }^{51}$ Nevertheless, sources

46. Id. (describing testimony that researchers recently discovered genetic and environmental causes for forms of parkinsonism previously considered idiopathic).

47. See supra Part II.A.

48. See supra notes 29,30 and accompanying text.

49. See, e.g., Torrejon v. Mobil Oil Co., 876 So. 2d 877, 892 (La. Ct. App. 2004); Anita Bernstein, Asbestos Achievements, 37 Sw. U.L. REv. 691, 703 (2008); Jamie A. Grodsky, Genomics and Toxic Torts: Dismantling the Risk-Injury Divide, 59 STAN. L. REV. 1671, 1730-31 (2007).

50. In re Asbestos Litig., 900 A.2d 120, 132 (Del. Super. Ct. 2006) ("[B] ackground incidence rate [of mesothelioma] is basically zero."); Osteen v. A. C. \& S., Inc., 307 N.W.2d 514, 518 (Neb. 1981) (describing evidence that "incidence of peritoneal mesothelioma is almost negligible in the population at large," estimated by plaintiff's expert to be one in 10,000 deaths); Gerald W. Boston, A Mass-Exposure Model of Toxic Causation: The Content of Scientific Proof and the Regulatory Experience, 18 COLUM. J. ENVTL. L. 181, 294 (1993) (stating incidence of mesothelioma in general population is approximately two per million).

51. See Osteen, 307 N.W.2d at 518 (noting that among asbestos workers, incidence of mesothelioma is approximately seven percent); TOD ZUCKERMAN \& MARK RASKOFF, 3 ENVIRONMENTAL INSURANCE LITIGATION: LAW AND PRACTICE $§ 26: 5$ n.5 (2010) (quoting Mark H. Beers et Al., The Merck Manual of Diagnosis And 
(including expert witnesses on both sides) report that asbestos exposures do not appear to account for ten to twenty percent or more of mesothelioma cases; such cases are generally considered idiopathic and attributed to "no known cause." 52 The proportion of idiopathic cases depends on two factors: the relative incidence of mesothelioma among exposed versus unexposed individuals, and the relative size of the exposed versus unexposed populations. If half, one-quarter, or one-eighth as many people had been exposed to asbestos at work, the percentage of all mesotheliomas not readily attributable to asbestos would be two, four, or eight times higher than it currently appears. Now that government regulation has eliminated the types of occupational exposure that led to the tragedy of asbestos workers' illnesses, presumably a time will come when virtually all of the (much lower) remaining incidence of mesothelioma in the United States will be "idiopathic." Assume

Therapy 472 (Robert S. Porter \& Thomas V. Jones eds., 18th ed. 2006)) (noting that asbestos workers have up to ten percent lifetime risk of developing mesothelioma); Irving Selikoff et al., Relationship Between Exposure to Asbestos and Mesothelioma, 272 NEw ENG. J. MED. 560 (1965) (documenting extremely high relative risk).

52. Becker v. Baron Bros., Coliseum Auto Parts, Inc., 649 A.2d 613, 618 (N.J. 1994) (reporting that plaintiff's witness testified that fifteen percent of cases "have no known cause," and defendant's witness testified that twenty to forty percent of cases have "unknown causes"); see also In re Joint E. \& S. Dist. Asbestos Litig., 129 B.R. 710, 740 (E.D.N.Y. 1991) (noting that fifty to eighty percent of diagnosed mesothelioma cases have history of asbestos exposure), vacated, 982 F.2d 721 (2d Cir. 1992), modified on reh'g, 993 F.2d 7 (2d Cir. 1993); Klima ex rel. Prior v. Volkswagen of Am., Inc., Nos. A095614, A095640, A097693, A097697, 2003 WL 22172417, at $* 4$ (Cal. Ct. App. Sept. 22, 2003) (noting that plaintiff's witness testified that twenty to thirty percent of cases in women and ten percent of cases in men are considered idiopathic); Osteen, 307 N.W.2d at 518 (documenting that studies show sixty to eighty percent of men dying of mesothelioma had prolonged occupational exposure to asbestos); Mark A. Behrens, What's New in Asbestos Litigation?, 28 REV. LiTIG. 501, 527 (2009) (asserting that "there is wide agreement that a significant number (by some estimates, twenty to thirty percent) of mesotheliomas are not asbestos-induced"); Troyen A. Brennan, Environmental Torts, 46 VAND. L. REV. 1, 15 (1993) (noting that "well over ninety-percent" of mesothelioma deaths are attributable to asbestos exposure); David C. Landin et al., Lessons Learned from the Front Lines: A Trial Court Checklist for Promoting Order and Sound Policy in Asbestos Litigation, 16 J.L. \& POL'y 589, 641 (2008) (reporting estimate of ten to twenty percent of mesotheliomas caused by "non-asbestos sources"). Some controversy exists over whether cases without obvious occupational exposure are truly idiopathic. See Becker, 649 A.2d at 618 (plaintiff's expert believed apparently idiopathic cases could be caused by asbestos in the atmosphere, while acknowledging that other small fibers or radiation could also cause mesothelioma); ZuCKERMAN \& RASKOFF, supra note 51, at $\S 26: 5$ n.5 (suggesting that apparently idiopathic cases could be related to overlooked exposures to asbestos). 
that at that time, a plaintiff sued who could prove significant asbestos exposure and who offered a witness willing to testify to specific causation based on epidemiologic studies and a differential diagnosis. It is hard to imagine that any court would exclude the proffered testimony because "the presence of a known risk factor is not a sufficient basis for ruling out idiopathic origin in a particular case ...." ${ }^{53}$

If sufficient evidence exists to infer that an agent causes (some of the cases of) a disease, the knowledge that an individual was exposed to the agent alters the probability that the agent caused that individual's case. Assume a disease for which all cases are either idiopathic or caused by exposure to agent $X$. For persons not exposed to agent $X$, all cases are idiopathic. It follows that the frequency of idiopathic cases among those exposed is lower than among the population as a whole. So, even if population-based data are treated as probability values in an individual case, it does not follow that (for example) if more than half of the cases of a disease are attributed to unknown causes, a plaintiff exposed to a known causative agent could never prove that the exposure more likely than not caused plaintiff's disease.

For agent $X$, the results of epidemiologic investigation, if they existed, would provide a population-based estimate of the extent to which exposure had altered the incidence of disease. ${ }^{54}$ In the case of asbestos, the powerful epidemiologic evidence linking exposure to mesothelioma distinguishes the hypothetical future plaintiff from many whose differential diagnoses were excluded because of a high proportion of idiopathic cases. The hypotheticals nonetheless demonstrate that what seems to be a specific causation problem of particularistic proof embraces a problem of population-based proof commonly associated with general causation. This brings us to the judicial treatment of epidemiology and relative risk.

53. Henricksen v. Conoco Phillips Co., 605 F. Supp. 2d 1142, 1162 (E.D. Wash. 2009).

54. Without epidemiologic data, a plaintiff would need to rely on other relevant evidence to support an inference of causation, which might include information about the extent of the plaintiff's exposure, the frequency in the population of exposure to the agent, and how convincingly exposure has been ruled out in the studies that generated the reported rate of idiopathic disease. If the hypothetical were relaxed to include the possibility of other known causes of the disease in addition to agent $X$, a plaintiff might also produce evidence ruling out those other known causes. 


\section{B. Judicial Treatment of Epidemiology}

Epidemiologists study the presence or absence of statistical associations between diseases and putative causes. Such associations, if accompanied by confirmatory factors tending to negate coincidence, can support an inference of a causal relation. ${ }^{55}$ Two essential attributes of epidemiology have largely framed judicial treatment of this science. Epidemiology's key strength is that its findings result from observation of living human beings. Epidemiology's key weakness is that its findings apply to the populations of living human beings from which a study's sample is drawn, rather than to any individual human being. ${ }^{56}$ These fundamental characteristics led many courts to address epidemiology from two seemingly contradictory directions. Courts have asked: can a plaintiff prove causation without epidemiologic support? Courts have also asked: can a plaintiff prove causation with only epidemiologic support—and if so, what must that support be?

From the first perspective, many courts have been leery of inference from animal or in vitro studies as proof of general causation. $^{57}$ In the Agent Orange litigation, for example, the court stated that epidemiologic studies of exposed human populationswhich in that case did not support plaintiffs' allegation of causation-were the "only useful studies having any bearing on causation." $" 58$ Many other courts have similarly treated

55. Gary H. Spivey, The Epidemiological Method, in ENVIRONMENTAL EPidemiology: EFFEcts of EnVIRONMENTAl CHEMicals on Human Health 9, 12-18 (William M. Draper ed., 1994).

56. In addition, the observational nature of epidemiology entails methodology problems of bias and confounding that can affect the validity of results, about which courts have sometimes expressed generalized concern. See Merrell Dow Pharms., Inc. v. Havner, 953 S.W.2d 706, 719 (Tex. 1997). For a discussion of the methodology problems, see George Maldonado, Interpreting Epidemiological Studies, in ENVIRONMENTAL EPIDEMIOLOGY: EFFECTS OF Environmental Chemicals on Human Health 29, 30-37 (William M. Draper ed., 1994).

57. See, e.g., Lynch v. Merrell-Nat'l Labs., 830 F.2d 1190, 1194 (1st Cir. 1987) ("Studies of this sort, singly or in combination, do not have the capability of proving causation in human beings in the absence of any confirmatory epidemiological data.”); Bell v. Swift Adhesives, Inc., 804 F. Supp. 1577, 1579-81 (S.D. Ga. 1992) (rejecting as insufficient an expert opinion based predominantly on animal studies).

58. In re "Agent Orange" Prod. Liab. Litig., 611 F. Supp. 1223, 1231-32 (E.D.N.Y. 1985) ("[S]tudies to date conclude that there is as yet no epidemiological evidence that paternal exposure to Agent Orange causes birth 
epidemiology as essential proof. ${ }^{59}$ This view has been most pronounced in cases where many epidemiologic studies exist that did not find an association between the alleged causal agent and the disease under study, ${ }^{60}$ but it has been stated in other situations as well. ${ }^{61}$ Courts have been less likely to require epidemiology if epidemiologic study of a particular alleged causal link is impractical, if the alleged toxicity is acute, or if the exposure is massive and idiosyncratic. ${ }^{62}$ But in many typical toxic tort cases-

defects and miscarriages .... Studies addressing the effect of Agent Orange exposure on veterans' health . . . have been negative or inconclusive.").

59. See, e.g., Raynor v. Merrell Pharms. Inc., 104 F.3d 1371, 1374 (D.C. Cir. 1997) (non-epidemiologic studies, "singly or in combination, are not capable of proving causation in human beings in the face of the overwhelming body of contradictory epidemiological evidence." (quoting Richardson v. RichardsonMerrell, Inc., 857 F.2d 823, 830 (D.C. Cir. 1988)); Brock v. Merrell Dow Pharms., Inc., 874 F.2d 307, 315 (5th Cir. 1989), modified on reh'g, 884 F.2d 166 (5th Cir. 1989) ("[S]peculation unconfirmed by epidemiologic proof cannot form the basis for causation in a court of law."); see Wells v. Smithkline Beecham Corp., 601 F.3d 375,380 (5th Cir. 2010) ("[T] his court has frowned on causative conclusions bereft of statistically significant epidemiological support.").

60. The Bendectin and breast implant cases are notable examples. Raynor, 104 F.3d at 1374 (treating as "controlling" the "overwhelming" body of negative results from epidemiologic study of Bendectin's alleged teratogenicity); In re Breast Implant Litig., 11 F. Supp. 2d 1217, 1227 (D. Colo. 1998) (excluding testimony of plaintiffs' general causation expert in part because of "a solid body of epidemiologic evidence establishing that breast implants do not cause" plaintiffs' conditions).

61. Burleson v. Tex. Dep't of Criminal Justice, 393 F.3d 577, 585-86 (5th Cir. 2004) (affirming exclusion of plaintiff's expert testimony and summary judgment for defendant because "one of the few, if not the only" epidemiologic study failed to find an association); In re Joint E. \& S. Dist. Asbestos Litig., 52 F.3d 1124, 1128 (2d Cir. 1995) ("[E]pidemiological evidence is indispensable in toxic and carcinogenic tort actions where direct proof of causation is lacking."); Bickel v. Pfizer, Inc., 431 F. Supp. 2d 918, 922 (N.D. Ind. 2006) ("Epidemiologic studies are the primary, generally accepted methodology for demonstrating a causal relation between a chemical and the set of symptoms or a disease." (quoting Rains v. PPG Indus. Inc., 361 F. Supp. 2d 829, 834 (S.D. Ill. 2004) (internal quotations omitted)); Cano v. Everest Minerals Corp., 362 F. Supp. 2d 814, 822 (W.D. Tex. 2005) ("Although Havner was a Bendectin case, [it] spoke generally about the use of epidemiological evidence . . . and the Court does not read the opinion to limit those principles solely to the Bendectin context."); Chambers v. Exxon Corp., 81 F. Supp. 2d 661, 664-65 (M.D. La. 2000) (excluding testimony of plaintiffs' causation experts because of lack of epidemiologic support for their opinions while rejecting expert's explanation that several studies' failure to find statistically significant associations resulted from rarity of plaintiffs' condition).

62. See, e.g., Hocraffer v. Sec'y of Health \& Human Serv., 63 Fed. Cl. 765, 77679 (2005) (reversing dismissal despite lack of epidemiologic evidence where plaintiff's experts testified that hepatitis B vaccine could be expected to cause Reye's syndrome in manner similar to other vaccines and they had ruled out other potential causes); Westberry v. Gislaved Gummi AB, 178 F.3d 257, 262 (4th Cir. 
involving diseases that occur at background rates in the population and result from exposure only after a latency period-the presence or absence of epidemiology can be critical. Even courts that do not formally deem epidemiology essential frequently characterize it as the "best" causation evidence.

From the second perspective, if epidemiology is essential or nearly essential evidence, what must the epidemiologic data (if believed) show to be sufficient to satisfy plaintiff's burden of proof? Epidemiologic studies report the extent to which exposure to a suspected toxin appears to increase the incidence of a disease, that is, the relative risk associated with exposure as compared to the unexposed. ${ }^{64}$ Relative risk is a property of a group rather than an individual plaintiff who unquestionably has a disease. Nevertheless,

1999) (affirming plaintiff's judgment based on differential diagnosis and temporal relationship despite lack of epidemiologic, animal, or in vitro evidence); Zuchowicz v. United States, 140 F.3d 381, 385 (2d Cir. 1998) (affirming plaintiff's judgment where both exposure and illness were so rare that epidemiologic study was impossible); Bowers v. N. Telecom, Inc., 905 F. Supp. 1004, 1010-11 (N.D. Fla. 1995) (holding that despite lack of "definitive" epidemiologic studies linking keyboard use to repetitive stress injuries, the large body of less definitive epidemiologic and other studies sufficed for admissibility and created material issue of fact); Alder v. Bayer Corp., 61 P.3d 1068, 1084-85, 1089-90 (Utah 2002) (reversing exclusion of plaintiff's expert testimony and summary judgment for defendant where plaintiff relied on differential diagnosis and temporal relationship to show that fumes from improperly vented x-ray developing machine caused mental impairment).

63. E.g., Beck v. Koppers, Inc., No. 3:03CV60-P-D, 2006 U.S. Dist. LEXIS 25519, at *10 (N.D. Miss. Feb. 2, 2006) (regarding epidemiologic studies as the best evidence even though they do not themselves "address the question of the cause of an individual's disease"); see also, e.g., Rider v. Sandoz Pharm. Corp., 295 F.3d 1194, 1199, 1203 (11th Cir. 2002) (stating that epidemiologic evidence is "not required" but affirming district court's exclusion of each of several other types of evidence that plaintiffs contended were collectively sufficient to prove causation); Ashburn v. Gen. Nutrition Ctrs., Inc., 533 F. Supp. 2d 770, 774 (N.D. Ohio 2008) (excluding testimony for failure to explain choice of methodology other than epidemiology); Lakie v. SmithKline Beecham, 965 F. Supp. 49, 56, 58 (D.D.C. 1997) (calling lack of epidemiologic evidence "important" yet admitting plaintiff's expert causation testimony).

64. Epidemiologic results may be reported as any of several values, depending on a study's design: relative risk, odds ratio, attributable risk or attributable fraction, standardized incidence ratio, or (if the studied outcome is death) standardized mortality ratio. Although their computations differ, conceptually these measures all describe the same thing, i.e. whether more disease is found in those exposed than among those not exposed. Michael D. Green et al., Reference Guide on Epidemiology, in Reference ManUal on SCIENTIFIC Evidence 333, 348-52 (2d ed. 2000) (describing relative risk, odds ratio, and attributable risk); see also Magistrini v. One Hour Martinizing Dry Cleaning, 180 F. Supp. 2d 584, 591 n.7 (listing several epidemiologic measures). 
beginning with the swine flu vaccine cases that entailed the first widespread use of epidemiology to address causation issues, courts have equated more than a doubling of relative risk in an exposed group to a more-likely-than-not probability of causation in an exposed individual plaintiff. ${ }^{65}$

This equation, combined with the rejection of general causation inferences that are based on non-epidemiologic evidence (such as animal studies), has substantive effect. It recasts the burden of proving causation as a requirement to produce epidemiologic evidence that satisfies the threshold. Courts hearing many types of toxic tort cases have defined the causation element in this way. ${ }^{66}$ The substantive definition leads to evidentiary consequences: courts have excluded expert testimony because the testimony was unsupported by epidemiologic studies showing relative risks greater than two. ${ }^{67}$

65. See, e.g., Cook v. United States, 545 F. Supp. 306, 308 (N.D. Cal. 1982) ("Whenever the relative risk to vaccinated persons is greater than two times the risk to unvaccinated persons, there is a greater than [fifty-percent] chance that a given GBS case among vaccinees of that latency period is attributable to vaccination, thus sustaining plaintiff's burden of proof on causation."); Padgett v. United States, 553 F. Supp. 794, 800-01 (W.D. Tex. 1982) ("From the relative risk, we can calculate the probability that a given case of GBS was caused by vaccination. ... [A] relative risk of 2 or greater would indicate that it was more likely than not that vaccination caused a case of GBS."); see also In re "Agent Orange" Prod. Liab. Litig., 597 F. Supp. 740, 836 (E.D.N.Y. 1984) (noting that if relative risk were not more than doubled, each plaintiff's claim would fail under preponderance standard).

66. Russellyn S. Carruth \& Bernard D. Goldstein, Relative Risk Greater than Two in Proof of Causation in Toxic Tort Litigation, 41 JuRIMETRICS J. 195, 200 (2001) (finding that relative risk of two is treated as threshold in approximately half of judicial opinions that discussed the issue); see also, e.g., Allison v. McGhan Med. Corp., 184 F.3d 1300, 1315 n.16 (11th Cir. 1999) ("The threshold for concluding that an agent more likely than not caused a disease is 2.0."); Hall v. Baxter Healthcare Corp., 947 F. Supp. 1387, 1403 (D. Or. 1996) (stating that plaintiffs must "demonstrate that exposure to breast implants more than doubled the risk" of alleged injuries); In re W.R. Grace \& Co., 355 B.R. 462, 483 (Bankr. D. Del. 2006) (requiring proof of relative risk greater than two to support property damage claims based on unreasonable risks posed by asbestos-contaminated insulation products).

67. See, e.g., Henricksen v. ConocoPhillips Co., 605 F. Supp. 2d 1142, 1158 (E.D. Wash. 2009) (noting that under Ninth Circuit precedent, epidemiologic studies may be probative of general causation but can prove specific causation only if relative risk exceeds two); $i d$. at 1175 (holding plaintiff's expert testimony inadmissible because epidemiologic evidence is "contradictory and inconsistent"); Pozefsky v. Baxter Healthcare Corp., No. 92-CV-0314, 2001 WL 967608, at*3 (N.D.N.Y. Aug. 16, 2001) (excluding testimony in light of negative epidemiology; sufficient epidemiologic proof requires relative risk greater than two); Watts v. Radiator Specialty Co., 990 So. 2d 143, 150 (Miss. 2008) (affirming exclusion of 
The absence of epidemiologic proof of a relative risk greater than two has been decisive even for courts that nominally resist conflation of a relative risk threshold with the standard of persuasion. It is one thing to permit non-epidemiologic evidence to suffice in cases of exposures and afflictions so rare that meaningful epidemiologic study is literally impossible. ${ }^{68}$ What if, as is frequently the case, such study is possible but of limited statistical power? ${ }^{69}$ In Dunn v. Sandoz Pharmaceuticals Corp. ${ }^{70}$ the plaintiff alleged that the drug Parlodel caused her stroke. ${ }^{1}$ Epidemiologic studies showed the relative risk for recently postpartum women who had taken Parlodel, compared to those who had not, was 8.4, but strokes were so rare in both groups the result was not statistically significant. ${ }^{72}$ The plaintiff's general causation expert was prepared to testify that the exposure and disease satisfied all the confirmatory factors epidemiologists usually rely on to confirm the credibility of a causal inference from an observed association. ${ }^{73}$ The court excluded the testimony, reasoning that the confirmatory factors were irrelevant absent a statistically significant epidemiologic result-even though the court also stated that

testimony based in part on lack of statistically significant epidemiology); cf. City of San Antonio v. Pollock, 284 S.W.3d 809, 818 (Tex. 2009) (testimony admitted without objection held insufficient as matter of law). But see Allen v. Martin Surfacing, 263 F.R.D. 47, 56 (D. Mass. 2008) (admitting causation testimony to be tested by adversary process, rather than excluded altogether, despite paucity of epidemiologic evidence); King v. Burlington N. Santa Fe Ry. Co., 762 N.W.2d 24, 46-47 (Neb. 2009) ("In short, significance of epidemiological studies with weak positive associations is a question of weight, not admissibility.").

68. See, e.g., Zuchowicz v. United States, 140 F.3d 381 (2d Cir. 1998). In Zuchowicz, the plaintiff's wife died of primary pulmonary hypertension (PPH) after receiving a massive overdose of the drug Danocrine. Id. at 384. The district court admitted testimony by plaintiff's causation experts, a physician and a pharmacologist. Id. at 385. Defendant argued that the testimony was both inadmissible and insufficient. Id. The Second Circuit affirmed the judgment for plaintiff, in part because "[t]he number of persons who received this type of overdose was simply too small for the plaintiff to be able to provide epidemiological, or even anecdotal, evidence linking PPH to Danocrine overdoses." Id.

69. Statistical power, a measure of a study's ability to rule out random error as a source of an observed association between exposure and disease, is a function of the size of the sample and the size of the effect being measured. Kaye \& Freedman, supra note 7, at 125-26.

70. 275 F. Supp. 2d 672 (M.D.N.C. 2003).

71. Id. at 675 .

72. Id. at 680 .

73. Id. at 676-79. 
epidemiologic proof is not required to prove causation. ${ }^{74}$

Courts that denied imposing a minimum relative risk threshold have meant less than they have said in other ways as well. Some courts have said that a relative risk greater than one, but less than two, is evidence of general causation but insufficient to prove specific causation. ${ }^{75}$ This distinction is unlikely to matter, however, in the typical case where particularistic proof of specific causation is inherently impossible. ${ }^{76}$ Similarly, courts have said that a relative risk less than two may be sufficient-if it is supplemented by other evidence. $^{77}$ Such statements, however, have tended to appear in the context of a finding that although such supplementation is permissible in principle, the plaintiff failed to achieve it in the case at bar. ${ }^{78}$

Finally, even courts that do not insist on proof of a doubling of risk nevertheless treat epidemiologic studies that do not demonstrate increased risk as definitive disproof of causation. ${ }^{79}$

74. Id. at 677-81, 684. The Kentucky Supreme Court, in another Parlodel case, criticized Dunn and similarly-reasoned decisions "as incorrectly requiring scientific certainty, which was not intended by Daubert." Hyman \& Armstrong, P.S.C. v. Gunderson, 279 S.W.3d 93, 104 (Ky. 2008).

75. In re Bextra \& Celebrex Mktg. Sales Practices \& Prod. Liab. Litig., 524 F. Supp. 2d 1166, 1172 (N.D. Cal. 2007); Pick v. Am. Med. Sys., Inc., 958 F. Supp. 1151, 1160 (E.D. La. 1997).

76. See Rosenberg, supra note 14, at 881 (explaining that both the "strong" version of preponderance rule-requiring particularistic evidence-and the "weak" version-requiring only relative risk greater than two-result in aggregate under-compensation if less than fifty percent of disease is attributed to exposure).

77. See also Hanford Nuclear Reservation Litig. v. E..I. DuPont, 292 F.3d 1124, 1137 (9th Cir. 2002) ("[W] hen available, known individual risk factors are also relevant" in addition to relative risk results from epidemiologic studies); $c f$. Estate of George v. Vt. League of Cities \& Towns, 993 A.2d 367, 381 (Vt. 2010) (paying lip service to idea that "some other evidence" besides epidemiologic report of relative risk greater than two could prove specific causation, but dismissing as unscientific plaintiff's expert's attempt to rely on such evidence).

78. E.g., Estate of George, 993 A.2d at 381; Pafford v. Sec'y of Health \& Human Servs., 451 F. 3d 1352, 1358-59 (Fed. Cir. 2006).

79. See, e.g., Hanford Nuclear Reservation Litig. v. E.I. DuPont, 534 F.3d 986, 1011, 1013-14 (9th Cir. 2008) (affirming exclusion of expert's proffered testimony that epidemiologic studies failing to show causation do not preclude causation); Brown v. Am. Home Prods. Corp., No. 99-20593, 2000 U.S. Dist. LEXIS 12275, at *29 (E.D. Pa. Aug. 28, 2000) ("[I]t is essential that any demonstration of causation ... compare the prevalence ... among those who took the drugs and a similarlysituated population of others who did not."); $i d$. at *177 (“[A]t least four epidemiologic studies confirmed that fenfluramines did not produce an increased risk of tricuspid regurgitation."); In re "Agent Orange" Prod. Liab. Litig., 611 F. Supp. 1223, 1231-32 (E.D.N.Y. 1985) (dismissing claims of plaintiffs who had opted out of class action), aff'd, 818 F.2d 187 (2d Cir. 1987). 
That conclusion is supportable if it is based on multiple, large, welldesigned studies, but it is not logically compelled in every case. Confounding factors and methodological flaws leading to biased results can obscure real associations just as they can generate spurious associations. Moreover, a study's limited statistical power, rather than the absence of a genuine association, may lead to statistically insignificant results that courts treat as disproof of causation, particularly in situations without the large study samples that result from mass exposures. ${ }^{80}$ Very few courts have recognized these possibilities. ${ }^{81}$

By contrast, many courts have imposed extremely strict standards on epidemiologic proof used to support a causal inference. The "high-water mark" of such decisions ${ }^{82}$ was a Bendectin case $^{83}$ decided by the Texas Supreme Court, Merrell Dow Pharmaceuticals $v$. Havner. ${ }^{84}$ Although the court denied that it was using relative risk greater than two as a "litmus test," Havner effectively imposed that threshold as a substantive requirement for a toxic tort plaintiff's proof of causation. ${ }^{86}$ At the

80. See Kaye \& Freedman, supra note 7, at 125-26 (defining statistical power and explaining that power "depends on the size of the effect and the size of the sample"); see also Smith v. Wyeth-Ayerst Labs. Co., 278 F. Supp. 2d 684, 693 (W.D.N.C. 2003) ("[T] he concept of power is key because it's helpful in evaluating whether the study's outcome . . . is exonerative or inconclusive.").

81. See, e.g., Cooley v. Lincoln Elec. Co., 693 F. Supp. 2d 767, 774 (N.D. Ohio 2010) (ruling that court would admit testimony that epidemiologic studies had not found statistically significant associations, but "will not allow any witness to opine that epidemiological studies . . . are evidence of an absence of an association ... unless the witness has performed a methodologically reliable analysis" of the studies' statistical power to support that conclusion); Smith, 278 F. Supp. 2d at 692-93 (refusing to conclude that epidemiologic study showing no increased risk disproved causation because very small number of cases of disease meant study had low statistical power).

82. Restatement (Third) of Torts: Liab. Physical \& Emotional Harm $§ 28$ cmt. c (2010).

83. Bendectin was a drug prescribed to treat morning sickness in pregnant women. Many plaintiffs alleged that Bendectin caused birth defects in children whose mothers took the drug. Michael D. GReEn, Bendectin AND BirTh Defects 2-3 (1996); Joseph SAnders, Bendectin on Trial: A Study of Mass TorT Litigation 1-2 (1998). The Bendectin cases are discussed in Part III.C. See infra notes 194-209 and accompanying text.

84. 953 S.W.2d 706 (Tex. 1997).

85. Id. at 718 .

86. See id. at 717-18 (referring to "requirement of more than a doubling of the risk"). In context, the "litmus test" remark emphasized that even if such epidemiologic data existed, it still might not satisfy plaintiff's burden. Id. at 718 ("We do not hold . . . that a relative risk of more than 2.0 is a litmus test or that a single epidemiological test is legally sufficient evidence of causation. Other factors 
same time, the Texas Supreme Court worried about using population-based data to infer causation in an individual case, ${ }^{87}$ and therefore imposed stringent "reliability" conditions on the use of epidemiologic studies-including a specific standard of statistical significance, ${ }^{88}$ and, perhaps most important, a requirement that a plaintiff "must show that he or she is similar to those in the studies." 89

On its face, the similarity requirement simply expresses the unremarkable view that evidence must be relevant. Judicial interpretation of the similarity requirement, however, is critical, for it confines an expert witness's ability to rely on data in support of inferences of causation. Havner, for example, stated that the similarity showing would require, among other things, proof that the injured person's "exposure or dose levels were comparable to or greater than those in the studies," apparently ruling out any inference based upon a lower exposure and a dose-response relationship. ${ }^{90}$

Havner treated the similarity requirement as an issue of evidentiary reliability. Most federal courts (and state courts that apply Daubert) address such issues under the rubric of evidentiary "fit," ${ }^{91}$ which empowers the court as gatekeeper to decide whether the purported basis for an expert's conclusion is sufficiently supportive or whether it leaves an "analytical gap"

must be considered.”). Most lower Texas courts and federal courts applying Texas law have construed Havner to require relative risk greater than two. E.g., Lofton v. McNeil Consumer \& Specialty Pharms., 682 F. Supp. 2d 662, 668 (N.D. Texas 2010); Wells v. SmithKline Beecham Corp., No. A-06-CA-126-LY, 2009 WL 564303, at *8 (W.D. Tex. Feb. 19, 2009); Cano v. Everest Minerals Corp., 362 F. Supp. 2d 814, 821-22 (W.D. Tex. 2005); Exxon Corp. v. Makofski, 116 S.W.3d 176, 182-83, 188 (Tex. Ct. App. 2003); Minn. Mining \& Mfg. Co. v. Atterbury, 978 S.W.2d 183, 198-99 (Tex. Ct. App. 1998).

87. Havner, 953 S.W.2d at 715, 718 (describing relative risk greater than two rule as "balance between the needs of our legal system and the limits of science").

88. The court embraced the ninety-five percent statistical significance convention, holding that for expert opinion based on an epidemiologic study to be admissible, the ninety-five percent confidence interval around the study's reported relative risk must not include a relative risk equal to one (i.e., no effect). Id. at 724 .

89. Id. at 720 .

90. See id.

91. Daubert v. Merrell Dow Pharms. Inc., 509 U.S. 579, 591 (1993) (explaining concept of "fit").

92. Gen. Elec. Co. v. Joiner, 522 U.S. 136, 137-38 (1997) (describing "analytical gap"); see also id. at 152-53 (Stevens, J., concurring in part and dissenting in part) (agreeing that proffered evidence did not "fit" but disagreeing 
allow the expert to testify. ${ }^{93}$ Courts, explicitly or implicitly, have invoked a lack of fit to support the dispositive exclusion of expert causation testimony in many factual contexts and for many different reasons. ${ }^{94}$

Many of these jurisprudential threads came together in the Vermont Supreme Court's 2010 decision in a worker's compensation case, Estate of George v. Vermont League of Cities $\mathcal{E}^{\circ}$ Towns. ${ }^{95}$ A firefighter's estate alleged that he had contracted nonHodgkin's lymphoma (NHL) as a result of exposure to carcinogens while fighting fires. ${ }^{96}$ The worker's compensation agency denied the claim for failure to prove a causal relation between the firefighter's employment and his illness. ${ }^{97}$ The estate appealed to the trial court, which excluded the estate's proffered expert testimony. $^{98} \quad$ By a 2-1-2 vote, the Vermont Supreme Court affirmed.

that it was unreliable).

93. See Sanders, supra note 20, at 1037-38 (noting importance of "fit" in court opinions).

94. See, e.g., Allison v. McGhan Med. Corp., 184 F.3d 1300, 1315-17 (11th Cir. 1999) (affirming exclusion of testimony in breast implant case, where testimony would have been based on animal studies of injected silicone and on four epidemiologic studies, but twenty epidemiologic studies found no association); Porter v. Whitehall Labs., Inc., 9 F.3d 607, 616 (7th Cir. 1993) (affirming exclusion of testimony based on animal studies because expert could not testify that chronology observed in animal models had occurred in plaintiff); Soldo v. Sandoz Pharms. Corp., 244 F. Supp. 2d 434, 568, 572 (W.D. Pa. 2003) (rejecting studies of related chemicals, animal models, or different diseases); Kerns v. Hobart Bros. Co., No. 2007 CA 32, 2008 WL 1991909, at *6 (Ohio Ct. App. May 9, 2008) (affirming exclusion of testimony for lack of epidemiologic study of plaintiff's industry, despite in vitro studies and epidemiologic studies of workers in other industries); Valentine v. PPG Indus., Inc., 821 N.E.2d 580, 595-96 (Ohio Ct. App. 2004) (rejecting inference from animal studies); In re BP Amoco Chem. Co., No. 14-06-00778-CV, 2007 Tex. App. LEXIS 446, at*6 (Tex. Ct. App. Jan. 25, 2007) ("Unless a plaintiff can show that he could qualify as a member of the exposed study group, an epidemiological study is irrelevant and misleading to the jury." (quoting Daubert, 509 U.S. at 591)). See generally Smith v. Wyeth-Ayerst Labs. Co., 278 F. Supp. 2d 684, 691 n.10 (W.D.N.C. 2003) ("The term 'fit' refers to the relationship of an epidemiological study to the facts of the case and the issues in dispute and involves evaluating the study's probative value.").

95. Estate of George v. Vt. League of Cities \& Towns, 993 A.2d 367 (Vt. 2010).

96. Id. at 369 .

97. Id.

98. Id. at 370 .

99. The concurring justice agreed with the plurality's analysis but considered the case "more as an adequacy-of-proof case than an admissibility-of-evidence case." Id. at 382 (Dooley, J., concurring). 
The extent of the firefighter's actual exposure to carcinogens was unknown and unknowable-no one had sampled and recorded the constituents of what he breathed while on the job. His estate relied on epidemiologic investigation of a suspected association between the firefighting profession and incidence of NHL. ${ }^{100}$ Claimant's experts referred to eight published studies, all of which reported elevated risks, though only some were statistically significant. $^{101}$ Two of the studies reported statistically significant relative risks greater than two. ${ }^{102}$ One of plaintiff's experts performed a meta-analysis which "found the summary risk estimate for NHL to be 1.51."103

The Vermont Supreme Court majority appeared willing to agree that this evidence might suffice to establish general causation, ${ }^{104}$ but Vermont "law requires claimant to show, not merely that firefighting increased the likelihood of injury, but that it more likely than not caused his disease." ${ }^{105}$ The judicial suspicion of inferences from group-based epidemiology to opinions about individual cases reverberated: "the very use of epidemiological evidence to show specific causation reflects a compromise, given that epidemiological studies 'cannot indicate the actual cause of a given individual's disease or condition."”106 Thus the court approved the trial judge's use of relative risk greater than two as a "benchmark" that "easily tied into Vermont's 'more likely than not' civil standard." widely varying degrees of relative risk" ${ }^{108}$ and only two of the eight

100. Id. at 373 .

101. Id. at 381 .

102. Id. at 387 (Reiber, C.J., dissenting).

103. Id. at 381. This figure would imply that just over one-third of all cases of NHL in a population of firefighters could be attributed to occupational exposures if the association were accepted as causal. Application of the relative risk greater than two threshold would mean that none of these firefighters received worker's compensation.

104. See id. at 376 (describing trial court finding that proof of "general association" did not prove "that claimant's work . . . actually caused him to develop NHL"); $i d$. at 381 ("A conclusion that NHL is considered a 'probable cancer risk' for firefighters is not sufficient to establish that claimant's NHL was caused by firefighting ....”).

105. Id. at 381 .

106. Id. at 377 (quoting Merrell-Dow Pharms., Inc. v. Havner, 953 S.W.2d 706, 718 (Tex. 1997)).

107. Id. at 375; see also id. at 378 ("[T] he trial court did not abuse its discretion in considering a relative risk greater than 2.0 as a reasonable and helpful benchmark under the circumstances presented here.”).

108. Id. at 375 . 
had statistically significant results showing more than a doubling of the risk, the court affirmed the exclusion of claimant's causation testimony and the resulting summary judgment in favor of the insurer. $^{109}$

The term "benchmark" suggests something less than "requirement," but it is far from clear what additional evidence the claimant might have introduced to vault the court's relative risk threshold. As the dissent noted, claimant's experts would have testified that several factors supported the inference that this particular firefighter faced higher occupational NHL risk than the average firefighter studied by the epidemiologists. ${ }^{110}$ The majority held, in effect, that none of this mattered, in light of epidemiologic evidence deemed insufficient. ${ }^{111}$ The holding demonstrates one consequence of the relative risk greater than two threshold: if an epidemiologic study's result satisfies the threshold requirement but a personal characteristic distinguishes a plaintiff from the members of the study's exposed sample group, courts reject the result as irrelevant to the particular plaintiff; ${ }^{112}$ but if an epidemiologic study's result does not meet the threshold, a plaintiff's personal characteristic cannot supply the needed increment of relative risk.

The Estate of George dissent also questioned the majority's conclusion that the wide range of reported relative risks favored exclusion of the proffered testimony. ${ }^{113}$ Variability in reported relative risks is common, ${ }^{114}$ and should be expected in any study

109. Id. at 375,382 .

110. Id. at 384 (Reiber, C.J., dissenting). The reasons advanced included: the number of years claimant had been a firefighter, the fact that his career included many years in which firefighters rarely used protective equipment, the type of NHL he had, and an analysis, akin to a differential diagnosis, that ruled out certain other risk factors. Id. at 393-94.

111. Id. at 376 ("To meet his burden of proof, claimant relied on epidemiological studies, studies that focus on general causation rather than specific causation."); id. at 392-93 (Reiber, C.J., dissenting) (arguing that claimant did not rely only on epidemiology).

112. See Merrell Dow Pharms., Inc. v. Havner, 953 S.W.2d 706, 720 (Tex. 1997).

113. Estate of George, 993 A.2d at 397 (Reiber, C.J., dissenting).

114. W. C. Hueper, Occupational and EnVironmental Cancers of the URINARY SYSTEM 118-19, 156 tbl.48 (1969) (describing studies reporting relative risks for bladder cancer among dye industry workers that ranged from 30 to 47 in early studies and 8.7 to 17 in studies conducted after production methods were changed to reduce toxic exposure); Yih-Horng Shiao, Genetic Signature for Human Risk Assessment: Lessons from Trichloroethylene, 50 ENVTL. \& MOlEculaR MuTAGENESIS 68, 72-73 (2009) (noting the epidemiology linking trichloroethylene to kidney cancer has been "inconsistent"). 
involving statistical sampling. The dissent wondered: if multiple epidemiologic studies exist, what percentage must show a relative risk greater than two to form a basis for an expert opinion? ${ }^{115}$ Echoing a criticism also found in legal scholarship, the dissent complained that the majority's "2.0 standard... requires each study to prove that claimant should win on the merits" rather than allowing a claimant to combine pieces of supporting evidence to meet the preponderance standard of proof.

The evidentiary and substantive rules illustrated in Estate of George and the opinions of many other courts differentially allocate to plaintiffs the cost of scientific uncertainty. By limiting legally admissible and sufficient proof to a specific category and strength of scientific results, these courts hold that plaintiffs must bear the cost of toxic injury uncompensated during the time when science is developing evidence but has not yet produced the judicially mandated results.

The treatment of epidemiologic uncertainty in Estate of George is a perfect example. Two of eight studies resulted in a statistically significant relative risk above the court's "benchmark" value of two. ${ }^{117}$ The opinion does not suggest that those studies suffered from some methodological flaw. ${ }^{118}$ Nevertheless, the studies were held not just insufficient to satisfy the claimant's burden and to raise a disputed issue of material fact, but insufficient even to provide enough support to allow an expert opinion to be admissible. ${ }^{119}$ In effect, the court held that the studies had no

115. Estate of George, 993 A.2d at 392-93, 397 (Reiber, C.J., dissenting).

116. Id. at 387; see also Lucinda M. Finley, Guarding the Gate to the Courthouse: How Trial Judges Are Using Their Evidentiary Screening Role to Remake Tort Causation Rules, 49 DePaul L. Rev. 335, 336 (1999) ("Judges have applied Daubert to subject each item of expert proof proffered by plaintiffs to substantive causation law scrutiny, to see if it, standing alone, would prove both general and specific causation."); Susan Haack, Proving Causation: The Holism of Warrant and the Atomism of Daubert, 4 J. HEALTH \& Biomedical L. 253, 272-73 (2008) (noting that, as an epistemological matter, "combined evidence may indeed warrant a causal conclusion better than any of its components"); McGarity, supra note 14, at 19-23 (noting that the judicial "corpuscular" approach, which emphasizes deficiencies of each piece of supporting scientific evidence, precludes use of "weight-of-theevidence approach" used by regulatory agencies in their decision-making to "protect[] citizens from toxic risks").

117. See supra notes $82-89$ and accompanying text.

118. Estate of George, 993 A.2d at 373 n.5 (noting that studies on which plaintiff relied, among others, were collected and described in a published literature review).

119. See supra notes 92,94 and accompanying text. 
probative value at all. ${ }^{120}$

When courts thus decide, in effect, that scientifically debatable conclusions are legally false, ${ }^{121}$ they do not simply restate that a plaintiff bears the burden of proof. They apply the preponderance standard in a way that does not treat errors equally but instead prefers false negatives over false positives.

Estate of George is all the more remarkable because the majority had to dance around its own precedent from a unanimous opinion just two years old that reversed a trial court's decision to exclude expert testimony that a defective microwave oven caused a fire. ${ }^{122}$ The earlier opinion criticized the trial judge for focusing too much on the expert's conclusions rather than on the methodology used to reach the conclusions. ${ }^{123}$ Emphasizing the "liberal thrust' of the rules of evidence," the court cautioned that consideration of expert testimony's admissibility should not serve "as a preliminary inquiry into the merits of the case." ${ }^{124}$ The dissent in Estate of George accused the majority of endorsing just such an inquiry. ${ }^{125}$ In the Vermont Supreme Court and many other courts, it seems, claims of

120. See Merrell Dow Pharms., Inc. v. Havner, 953 S.W.2d 706, 712 (Tex. 1997) ("While Rule 702 deals with the admissibility of evidence, it offers substantive guidelines in determining if the expert testimony is some evidence of probative value.").

121. See, e.g., Milward v. Acuity Specialty Prods. Grp., 664 F. Supp. 2d 137, 146 (D. Mass. 2009) (holding that expert testimony must be excluded as unreliable if expert's conclusion is subject to scientific debate and the consensus is " $[\mathrm{w}] \mathrm{e}$ don't know"), rev'd, No. 09-2270, 2011 WL 982385 (1st Cir. Mar. 22, 2011); see also Susan Haack, Federal Philosophy of Science: A Deconstruction—and a Reconstruction, 5 N.Y.U.J. L. \& LiBERTY 394, 412 (2010) (criticizing Daubert for conflating "scientific" with "reliable"). For discussion of the First Circuit's opinion in Milward, see infra Part IV.D.2.

122. 985 Assocs. v. Daewoo Elecs. Am., Inc., 945 A.2d 381, 382 (Vt. 2008). The composition of the Vermont Supreme Court did not change in the time between 985 Associates and Estate of George. See Vermont Supreme Court Justices'Biographies, VERMONTJUDICIARY.ORG, http://www.vermontjudiciary.org/GTC/Supreme /JusticesBios.aspx (last visited Jan. 21, 2011).

123. 985 Assocs., 945 A.2d at 385, 387 (“[T] he trial court's reasoning was flawed with regard to its determination that plaintiffs' expert opinions were unreliable and therefore inadmissible" because the court "focus[ed] on the conclusions drawn by the experts, rather than on the reliability of the underlying facts and methodology employed in reaching those conclusions."). Those who think courts too readily exclude toxic tort causation witnesses often echo this criticism. Finley, supra note 116, at 342-44; Haack, supra note 116, at 260.

124. 985 Assocs., 945 A.2d at 385.

125. Estate of George v. Vermont League of Cities \& Towns, 993 A.2d 367, 383 (Vt. 2010) (Reiber, C.J., dissenting) ("[B] oth the trial court and the majority have exceeded their proper roles in this case and evaluated the evidence put forward by claimant to determine whether claimant should ultimately prevail on the merits."). 
toxic tort causation have received special scrutiny. What explains that?

\section{WHY DOES THE FALSE NEGATIVE ASYMMETRY EXIST, AND IS IT JUSTIFIED?}

The judicial preference for false negatives in toxic causation claims is never expressly acknowledged and only rarely implicitly explained. Searching for the causes of and justifications for the false negative asymmetry, then, is to some degree an inherently speculative enterprise. This Part assesses rationales that can be inferred from judicial and scholarly writings.

Might plaintiffs' problems in toxic tort cases simply reflect a systemic judicial bias in favor of a politically conservative, probusiness, anti-plaintiff ideology? Few would question that, for example, the judges who compose the federal bench are on average more politically conservative today than they were thirty years ago. ${ }^{126}$ Nevertheless, the judicial ideology explanation falls short because, heuristically, toxic tort causation rulings do not seem to break along political lines of division.

The principal holdings of the three major Supreme Court opinions on expert testimony "gatekeeping," for example, were all supported by unanimous courts. ${ }^{127}$ Justice Stevens dissented in part from all three holdings, but the other members of the Court's "liberal" wing ${ }^{128}$ did not join him. In Joiner and Kumho he was alone, arguing in each case that the Court needlessly went beyond the legal question presented to decide that the district court had not abused its discretion in excluding the plaintiff's proffered expert testimony. $^{129}$ In Daubert-a Bendectin case-Justice Stevens joined

126. See Michael Waldman, A Brewing Court Battle, Newsweek, Mar. 14, 2009, available at http://www.newsweek.com/2009/03/13/a-brewing-court-battle.html ("For the past quarter century, the courts have been conservative ....").

127. Kumho Tire Co. v. Carmichael, 526 U.S. 137, 139-40 (1999) (unanimous with a dissent in part by Justice Stevens); Gen. Elec. Co. v. Joiner, 522 U.S. 136, 137-38 (1997) (unanimous with a dissent in part by Justice Stevens); Daubert v. Merrell Dow Pharms., Inc., 509 U.S. 579, 580 (1993) (unanimous with a dissent in part by Justice Stevens).

128. See, e.g., Jeffrey Rosen, The Dissenter, Justice John Paul Stevens, N.Y. TIMES, Sept. 23, 2007 (Magazine) (noting that in the immediately preceding Supreme Court term, "[t]he four more liberal justices were often moved to dissent in unusually personal and vehement terms" and describing Justice Stevens as "arguably [the] most liberal justice").

129. Kumho, 526 U.S. at 159 (Stevens, J., dissenting); Joiner, 522 U.S. at 154-55 (Stevens, J., dissenting). 
Chief Justice Rehnquist's partial dissent from the majority's articulation of "general observations" concerning the types of considerations that might guide district courts trying to decide whether to admit expert testimony. ${ }^{130}$ Their dissent famously warned that the Court, unwisely, was forcing judges to become "amateur scientists" in deciding admissibility disputes. ${ }^{131}$

Even before the Supreme Court's Daubert opinion, every federal appellate court that considered the causation issue in a Bendectin case had rejected the plaintiffs' claim. The majority of judges involved in those decisions were appointed by President Reagan, but the few who were appointed by Democratic presidents did not disagree. ${ }^{132}$ Similarly, it is not difficult to find cases, after Daubert and Joiner, in which judges appointed by Democrats adopted restrictive views of causation evidence and judges appointed by Republicans were more accepting. ${ }^{133}$ The riven Fifth

130. Daubert, 509 U.S. at 598-601 (Rehnquist, C.J. dissenting). Electronic database searches of the Court's opinions showed that Daubert is one of only eleven instances in which a dissenting or partially dissenting opinion was joined by Justices Rehnquist and Stevens and no other Justices.

131. Id. at $600-01$.

132. For a chronological list of forty-nine appellate Bendectin opinions, representing thirty-four Bendectin cases, see SANDERS supra note 83, at 156, 157 tbl.15 (1998). The list includes seven decisions of federal courts of appeals before the Daubert Supreme Court opinion. See id. at 157 tbl.15. Publically available information about these judges and their appointing presidents shows that of the twenty-one judges on those seven panels (including two sitting by designation), eleven were appointed to their then-current seats by President Reagan, and only six were appointed by Democrats. The latter six included the following judges: (1) the author of one of the earliest cases, Richardson ex rel. Richardson $v$. RichardsonMerrell, Inc., 857 F.2d 823, 824 (D.C. Cir. 1988) (affirming defendant's judgment notwithstanding the verdict); (2) all three judges on the unanimous ruling, later cited by the Supreme Court, of Turpin v. Merrell Dow Pharmaceuticals, Inc., 959 F.2d 1349, 1350 (6th Cir. 1992) (affirming defendant's summary judgment); and (3) a member of a panel that issued a per curiam opinion that followed the Turpin precedent, Lee v. Richardson-Merrell, Inc., No. 91-5369, 1992 WL 92750, at *2 (6th Cir. Apr. 22, 1992) (per curiam). Two of the seven appeals affirmed judgments for defendants that had been entered by district judges appointed by President Carter. SANDERS, supra note 83, at 157 tbl.15.

133. Compare Henricksen v. ConocoPhillips Co., 605 F. Supp. 2d 1142, 1178 (E.D. Wash. 2009) (judge appointed by Democratic president excludes plaintiff's experts' testimony for lack of fit and failure to assess possible particularistic evidence), with Allen v. Martin Surfacing, 263 F.R.D. 47, 64 (D. Mass. 2009) (judge appointed by Republican president holds that defendant's attacks on plaintiff's experts' methodology and conclusions go to the weight, rather than admissibility, of the evidence); see Milward v. Acuity Specialty Prods. Group, Inc., No. 09-2270, 2011 WL 982385 (1st Cir. Mar. 22, 2011) (unanimous court of appeals panel consisting of two judges appointed by President Clinton and one judge appointed by President G.W. Bush reverse exclusion of plaintiffs' expert by district judge 
Circuit in Huss $v$. Gayden provides an interesting example of a split that did not strictly follow party lines. ${ }^{134}$ The same non-pattern appears in the opinions of state courts. The Texas Supreme Court took a restrictive view of causation evidence, ${ }^{135}$ but so did the Vermont Supreme Court-with one of two Republican-appointed justices and one of three Democrat-appointed justices dissenting. ${ }^{136}$ The highest courts in Nebraska and Kentucky rejected arguments for similarly restrictive views. ${ }^{137}$ The political party of a judge's appointing executive is an imperfect ideological proxy, and these results are impressionistic rather than comprehensive, but they suggest that more than political ideology is at play in toxic tort causation decisions. ${ }^{138}$

appointed by President Clinton).

134. Huss v. Gayden, 571 F.3d 442 (5th Cir. 2009), reh'g en banc denied, 585 F.3d 823 (2009). A panel majority, consisting of one appointee of President George H.W. Bush and one appointee of President George W. Bush, reversed the plaintiff's jury verdict, holding-over a dissent by an appointee of President Reagan-that the exclusion of a defense expert on causation had been an abuse of discretion. Huss, 571 F.3d at 455-56 (holding exclusion was reversible error meriting a new trial); $i d$. at 463 (Higginbotham, J., dissenting). Nine judges dissented from the denial of panel rehearing en banc. Huss, 585 F.3d at 827 (Higginbotham, J., dissenting); $i d$. at 833 (Elrod, J., dissenting). All of the judges who voted against the rehearing were appointed by Republican presidents. All four judges on the court who were appointed by Democratic presidents dissented from the denial of rehearing-joined by four appointees of Republican presidents.

135. See Merrell Dow Pharms., Inc. v. Havner, 953 S.W.2d 706, 714-20 (Tex. 1997) (setting forth various requirements for scientific evidence of toxic tort causation); see supra notes 84-90 and accompanying text (analyzing Havner).

136. See Estate of George v. Vt. League of Cities \& Towns, 993 A.2d 367, 382 (Vt. 2010); see id. at 383 (Reiber, C.J., dissenting); supra notes 95-116 and accompanying text (analyzing Estate of George).

137. See Hyman \& Armstrong, P.S.C. v. Gunderson, 279 S.W.3d 93, 105 (Ky. 2008) ("Daubert does not require proof to a scientific certainty, or even proof convincing to the trial judge. The trial judge is not required to find that the proffered opinion is scientifically correct, but only that it is trustworthy . . .."); King v. Burlington N. Santa Fe Ry. Co., 762 N.W.2d 24, 42-43 (Neb. 2009) ("[R] easonable differences in scientific evaluation should not exclude an expert witness' opinion. The trial court's role as evidentiary gatekeeper is not intended to replace the adversary system .....").

138. See Tracy E. George, Developing a Positive Theory of Decisionmaking on U.S. Courts of Appeals, 58 OHIO ST. L.J. 1635, 1651-53 (1998) (stating that the appointing president's political party is "a good proxy for a justice's attitudes"). But see Gregory C. Sisk \& Michael Heise, Judges and Ideology: Public and Academic Debates About Statistical Measures, 99 Nw. U. L. REv. 743, 793-94 (2005) (“[A]t least at the lower federal court level, ideology explains only part of judicial behavior and tends to emerge in certain narrowly defined sets of cases in studies designed to tease out those marginal effects."). 
Courts that erect high sufficiency thresholds and narrow admissibility walls for toxic tort causation evidence frequently exhibit heightened sensitivity to the truth-seeking function of law and emphasize the goal of accurate fact-finding. ${ }^{139}$ The issue is why this sensitivity should take the form of decision rules that create asymmetrical risks of error.

\section{A. The Science Rationale: Courts as Serfs of Statistics}

Our courts take for granted that deciding a toxic causation dispute is inherently beyond the ken of lay people and therefore demands expert scientific testimony. ${ }^{140}$ Because the testimony is scientific, courts often conflate resolution of these legal disputes with a search for scientific truth, ${ }^{141}$ although the epistemic nature and systemic goals of legal and scientific inquiry diverge. ${ }^{142}$ Framing disputes as scientific creates the expectation, sometimes

139. See Sanders, supra note 20, at 1045-47.

140. E.g., Allison v. McGahn Med. Corp., 184 F.3d 1300, 1320 (11th Cir. 1999) (holding expert testimony required because causal connection "is not a natural inference that a juror could make through human experience."); Henricksen v. ConocoPhillips Co., 605 F. Supp. 2d 1142, 1177 (E.D. Wash. 2009) ("Expert testimony is necessary . . . since this is a toxic tort lawsuit."). Other approaches are conceivable. In a medical malpractice case, the Supreme Court of Canada affirmed a finding that an ophthalmologist's negligence caused atrophy of the plaintiff's optic nerve even though plaintiff suffered from other conditions known to cause atrophy and the expert witnesses could not "express with certainty an opinion as to what caused the atrophy in this case ..." Snell v. Farrell, [1990] 2 S.C.R. 311, para. 7 (Can.). For a generalized defense of that outcome, see Brown, supra note 2 , at 35 (arguing that "[n] either the existence of an evidentiary gap nor scientific demurral from bridging that gap excuses the fact-finder from proceeding further in the causal inquiry. Reliance on scientific demurral as being determinative is, quite literally, unjust."); see also Gass v. Marriott Hotel Servs., Inc., 558 F.3d 419, 434 (6th Cir. 2009) (affirming exclusion of plaintiffs' doctors' causation opinions, but reversing summary judgment for defendant, because a jury could rationally find for plaintiffs if it believed plaintiffs' testimony that they suffered immediate and lasting illness after exposure to a cloud of pesticide sprayed in their hotel room); Genna v. Jackson, 781 N.W.2d 124, 129-30 (Mich. App. 2009) (holding expert causation testimony unnecessary where children developed symptoms after mold grew in home and recovered when the children were removed from the home), appeal denied, 783 N.W.2d 350 (2010).

141. Sanders, supra note 20, at 1045 .

142. See, e.g., Carl F. Cranor, Toxic TORTs 207-15 (2006) (describing tensions between scientific and legal goals and epistemic practices); Troyen A. Brennan, Causal Chains and Statistical Links: The Role of Scientific Uncertainty in HazardousSubstance Litigation, 73 CORNELL L. REV. 469, 471 (1988) ("Legal notions of causation, however, differ in important ways from scientific causal concepts.”); Walker, supra note 2, at 1096 (noting that legal fact-finding must satisfy policies and goals not applicable to science). 
illusive, that an objectively correct, indisputable answer is available. $^{143}$ This "scientific turn" of toxic tort causation jurisprudence $^{144}$ cannot be separated from the tendency to privilege litigation's truth-seeking function at the expense of other legitimate functions; the two trends reflect and reinforce each other. ${ }^{145}$ As one judge, melding the concepts, argued: "[c] ourts must be arbiters of truth, not junk science and guesswork." "146

If, as some have charged, many courts equate "preponderance of the evidence" of toxic causation with scientific certainty of causation, ${ }^{147}$ that provides some accounting for the false negative asymmetry. A rule that demands certainty necessarily would lead to false negatives by excluding even probable but uncertain positive findings.

Courts, naturally, do not acknowledge demanding certainty, and when they inadvertently sound like they do, they correct themselves. For example, when an appellate panel in a Bendectin case found "the lack of conclusive epidemiological proof to be fatal" to plaintiffs' case, on petition for rehearing it instead found fatal plaintiffs' "failure to present statistically significant epidemiological proof." ${ }^{\prime 148}$ The word substitution achieved quite a transmutation.

143. The same illusion is said to afflict jurors in criminal cases who suffer from the "CSI effect." See N.J. Schweitzer \& Michael J. Saks, The CSI Effect: Popular Fiction About Forensic Science Affects the Public's Expectations About Real Forensic Science, 47 JURIMETRICS J. 357 (2007) (testing the hypothesis that television shows highlighting forensic science make jurors less inclined to convict if the prosecution presents no scientific evidence and/or more inclined to convict if the prosecution presents any scientific evidence).

144. Sanders, supra note 20, at 1045; see also SANDERS, supra note 83, at 159-60 (tracing shift in appellate decisions in Bendectin cases from "legalistic" view less likely to resolve conflicts between experts to "scientific" view tending to scrutinize the basis for expert opinions and rule on causation as a matter of law).

145. See Sanders, supra note 20, at 1045. For criticism of the high value courts place on truth-seeking in toxic tort litigation, see Brown, supra note 2, at 18-20, 23-24 and CRANOR, supra note 142, at 349.

146. Huss v. Gayden, 571 F.3d 442, 460 (5th Cir. 2009) (plurality opinion).

147. E.g., Hyman \& Armstrong, P.S.C. v. Gunderson, 279 S.W.3d 93, 104 (Ky. 2008) (rejecting defendant's challenge to trial court's admission of plaintiff's expert testimony on causation and criticizing rejection of similar evidence by other courts "as incorrectly requiring scientific certainty, which was not intended by Daubert").

148. Brock v. Merrell Dow Pharms., Inc., 884 F.2d 166, 167 (5th Cir. 1989) (emphasis added). Another example is In re Joint S. E E E. Dist. Asbestos Litig., 52 F.3d 1124, 1128 (2d Cir. 1995) (noting that district court had held that plaintiff could introduce proof of causation sufficient to reach jury "either through studies conclusively establishing" relative risk greater than two or through epidemiologic evidence of relative risk less than two combined with particularistic evidence 
The court's original sentence appeared to abandon the preponderance standard in favor of a demand for evidence stronger even than that required for a criminal conviction. The rephrased sentence amounted to a nearly banal statement that the court would not accept, as evidence of an effect, a result that did not satisfy the scientific convention for acceptance of evidence of an effect.

The scientific convention begins with the null hypothesis-the assumption that an effect under investigation does not exist-and demands proof that it is very unlikely an observed difference between two samples would have been found had the parametric values been the same in the two populations from which the samples were drawn. "Very improbably" conventionally has meant a probability of less than five-percent. ${ }^{150}$ Statistical significance testing helps scientists avoid Type I error (incorrectly rejecting a null hypothesis that is true), but conveys no information about the probability of a Type II error (incorrectly failing to reject a null hypothesis that is false). ${ }^{151}$ The latter can be quite high, depending on the statistical power of feasible research designs. Implicit in scientists' choice to avoid Type I error and tolerate a risk of Type II error is the assumption that if an investigated effect really exists, it will eventually be demonstrated by repeated, and preferably improved or enlarged, studies. ${ }^{153}$

strengthening the causal inference).

149. This is typically represented as " $P<.05$," and is equivalent to "statistical significance at the $95 \%$ level." Lower values of $P$ provide greater confidence in rejection of the null hypothesis. See Kaye \& Freedman, supra note 7, at 122.

150. See id. at 124.

151. Id. at 125-26, 168, 172-73; Michael I. Meyerson \& William Meyerson, Significant Statistics: The Unwitting Policy Making of Mathematically Ignorant Judges, 37 PEPP. L. REV. 771, 825 (2010).

152. See Kaye \& Freedman, supra note 7, at 125-26 (explaining that subtle effects require large sample sizes for detection).

153. This discussion is not intended to suggest that a court's refusal to admit expert opinion based on study results that are not statistically significant is equivalent to imposing a heightened standard of persuasion that demands $95 \%$ certainty. No scientist would consider a result that is "significant" at the $51 \%$ level $(P<.49)$ to mean that it is "more likely than not" that an observed difference between two samples reflected a real difference between the parametric values in the population: such a result would be obtained $49 \%$ of the time even if the parametric values were the same, so it would provide no reasonable basis for rejecting the null hypothesis. The choice of a $95 \%$ significance level, however, is arbitrary, and the difference between "significant" and "not significant" does not reflect a sharp yes-or-no division in the real world. Meyerson \& Meyerson, supra note 151, at 824 . Results that are not statistically significant may simply be 
Epidemiology goes further and maintains a particular ethos that is "inherently conservative in its reluctance to abandon the null hypothesis." 154 This reluctance is substantially rooted in the nature of epidemiology as an observational, rather than experimental, science. ${ }^{155}$ Epidemiologists guard especially carefully against incorrect causal attributions, seeking not only reproducible epidemiologic results but other confirmatory evidence of the causal nature of an observed association. ${ }^{156}$ A scientific case for any particular claim of toxic causation builds, if it builds at all, by accretion.

To the extent, therefore, that courts refuse to permit a factfinder to assess expert testimony during the time the scientific case is under construction, the law will avoid false positives at the expense of allowing false negatives. But simply to say that "[1]aw lags science; it does not lead it" ${ }^{\prime 157}$ is to beg the question. Even if one accepts that toxic tort causation must be scientifically proven, it takes an exercise of judicial discretion to determine what constitutes admissible scientific proof and what constitutes scientific proof sufficient to create a genuine dispute of material fact. The false negative asymmetry manifests not so much in courts' judgment that science is required but in their judgment of what science is required, which involves much more than the

\footnotetext{
reported as $P>.05$, which does not distinguish between a result that nearly reaches the $95 \%$ significance level $(e . g ., P<.07)$ and a result that does not come close $(e . g$., $P<.49)$. A study of limited statistical power that produced a result "significant" at the $93 \%$ level could indicate that a more powerful study is warranted, and could-particularly if supported by other evidence-appropriately be considered legally relevant. On the other hand, for some applications, scientists consider the $95 \%$ significance level not nearly stringent enough. For example, when biologists search the human genome for associations between genetic variations and elevated risk of disease, they test so many genes that to set the acceptable Type I error rate at $5 \%$ would produce vast numbers of purely coincidental associations. They use a standard that is orders of magnitude stricter. Karen N. Conneely \& Michael Boehnke, Meta-Analysis of Genetic Association Studies and Adjustment for Multiple Testing of Correlated SNPs and Traits, 34 GENETIC EPIDEMIOLOGY 739, 739 (2010) (noting the "common approach" in genome-wide association studies of using a cutoff of $P<5 * 10^{-8}$ ).

154. Finley, supra note 116, at 364 .

155. See Green, supra note 64, at 336, 374-75 (distinguishing between epidemiologic observation of associations and causal attribution).

156. Id. at 375-79 (describing Bradford Hill confirmatory factors).

157. Rosen v. Ciba-Geigy Corp., 78 F.3d 316, 319 (7th Cir. 1996); see also Sanderson v. Int'l Flavors \& Fragrances, Inc., 950 F. Supp. 981, 1003 (C.D. Cal. 1996) (finding plaintiff must wait for proof to develop at "laggardly" pace of science).
} 
transitive application of scientific norms of statistical significance.

Thus, where courts have held that causation testimony should not be considered because the expert would have relied on the results of toxicology studies in animal models or in vitro, or on chemical structure analogies, or on epidemiologic studies of people whose personal or exposure characteristics differed from the plaintiff in some way, they rarely concluded that these studies suffered from methodological flaws that invalidated their conclusions as a matter of quality control within their respective disciplines. Methodological reliability of the scientific evidence, the keystone to Daubert, has faded in significance; fit has become the "central question." A 158 judge's most critical decision, frequently, is whether or not to reject out of hand a causal inference that an expert is willing to make from the extant scientific research. ${ }^{159}$

The courts' resistance to scientific inference of toxic tort causation has been widespread and powerful. ${ }^{160}$ When courts refuse to admit testimony by well-credentialed experts based on well-conducted studies, they do more than demand that litigation achieve scientific truth. They define what scientific proof is for juridical purposes. ${ }^{161}$ In doing so, they make a legal, not a scientific, judgment.

Estate of George ${ }^{162}$ again provides an illustration. One of plaintiff's experts, attempting to assemble the disparate epidemiologic results and the known information about the deceased firefighter, would have testified that he reached his conclusion of causation by applying the "weight of the evidence"

158. Sanders, supra note 20, at 1037-38. ("In the aftermath of Joiner and Kumho Tire, federal-court admissibility decisions focus less on the Daubert factors and more on a fit analysis. The central question in these opinions was whether there is too large an analytical gap between the evidence available to the expert and the conclusion the expert wishes to draw.").

159. Id.

160. CRANOR, supra note 142, at 221-64 (giving numerous examples); Erica Beecher-Monas, The Heuristics of Intellectual Due Process: A Primer for Triers of Science, 75 N.Y.U. L. REV. 1563, 1647 (2000) (describing a toxic tort causation case as an example of "the general judicial unwillingness to reason by analogy in assessing scientific evidence"); see, e.g., Downs v. Perstorp Components, Inc., 126 F. Supp. 2d 1090, 1125-28 (E.D. Tenn. 1999) (giving examples of such inference that the court considers fundamentally unscientific and improper).

161. See Sanders, supra note 20, at 1042-43 (describing basis for rejection of studies relied on by plaintiff's proffered experts in Joiner as Chief Justice Rehnquist's "implicit external-validity criteria”).

162. Estate of George v. Vt. League of Cities \& Towns, 993 A.2d 367 (Vt. 2010). 
approach. ${ }^{163}$ The court rejected the expert's invocation of this approach because the expert could not state the "precise weight he

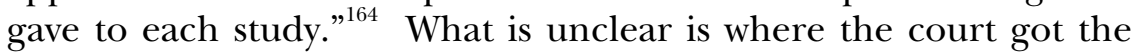
idea that such precision-presumably in quantitative terms-was required for the testimony to be scientifically reliable and thus admissible. ${ }^{165}$

The courts have not been simply "prisoner[s] to science."166 Rather, many have heeded the Fifth Circuit's admonition "in subsequent toxic tort cases to be especially vigilant in scrutinizing the basis, reasoning, and statistical significance of studies presented by both sides." 167 "By both sides" is a fig leaf. Because plaintiffs bear the burden of proof, "especially vigilant" scrutiny will always affect plaintiffs more than defendants. ${ }^{168}$ And "especially vigilant" is a legal, not a scientific, standard.

The scientific nature of the causal inquiry and the courts' adoption of concepts of scientific validity and statistical significance have contributed importantly to the creation of a jurisprudence that preferentially risks incorrect negative rather than positive legal findings. But the false negative asymmetry is not a necessary result of, and cannot entirely be explained by, acceptance of an axiom that scientific truth be the standard for claims of toxic tort causation.

163. Id. at 376 .

164. Id. at 379 .

165. Cf. King v. Burlington N. Santa Fe Ry. Co., 762 N.W.2d 24, 39-40 (Neb. 2009) (" $[\mathrm{N}]$ o generally agreed-upon method exists for determining how much weight to apply to particular types of studies.").

166. Estate of George, 993 A.2d at 382 (quoting Sanderson v. Int'l Flavors \& Fragrances, Inc., 950 F. Supp. 981, 1004 (C.D. Cal. 1996)).

167. Brock v. Merrell Dow Pharms., Inc., 884 F.2d 166, 166 (5th Cir. 1989) (amending Brock v. Merrell Dow Pharms., Inc., 874 F.2d 307 (5th Cir. 1989)).

168. Furthermore, to demand "statistical significance" for studies that fail to find an association between exposure and disease makes no sense, because statistical significance is used only to minimize the likelihood that scientists accept false positive results. It might make sense, before accepting such a study as providing evidence of no causation, to demand a showing that the study had sufficient statistical power to find an effect if it existed. 


\section{B. The Legitimacy Rationale: Courts in Need of Respect}

Elemental notions of justice underlie the requirement of a causal connection between defendant's act and plaintiff's harm. ${ }^{169}$ We want fact-finders to believe that the defendant actually caused the harm, which is why, despite the probabilistic language of the preponderance standard, courts traditionally were uncomfortable with using "naked" statistical evidence to establish causation. ${ }^{170}$ Courts' increasing willingness to accept epidemiologic data as relevant to causal determinations in individual cases represented a pragmatic shift from the dogma that "mere statistics" could never be sufficient to hold a party liable for particularized harm. The group-based nature of epidemiologic proof and the existence of mass exposures, however, emphasized that the general causation inquiry applied to the entire group. Some courts worried openly about the prospect of inconsistent jury determinations, ${ }^{171}$ and judges have used their gatekeeping power to "resolve whole categories of toxic torts" for failure to show general causation. ${ }^{172}$

169. See Robert A. Baruch Bush, Between Two Worlds: The Shift from Individual to Group Responsibility in the Law of Causation of Injury, 33 UCLA L. REV. 1473, 1474 (1986) (noting that the actual causation requirement of proof that an "individual defendant's conduct, and not someone else's," caused harm is consistent with tort law's individual responsibility principle). A defendant's interest in not being unfairly held liable for harm the defendant did not cause is obvious. Even from a plaintiff's point of view, however, corrective justice ultimately is hollow if the party held liable did not do the harm. Id. at 1476. From a deterrence perspective, both false positive causal attributions and false negatives rejections of causation result in deviations from optimum deterrence.

170. See, e.g., Howard v. Wal-Mart Stores, Inc., 160 F.3d 358, 359-60 (7th Cir. 1998); Charles Nesson, Agent Orange Meets the Blue Bus: Factfinding at the Frontier of Knowledge, 66 B.U. L. REv. 521 (1986) (highlighting that a determination of what happened may seem speculative despite its statistical probability); Richard W. Wright, Liability for Possible Wrongs: Causation, Statistical Probability, and the Burden of Proof, 41 LoY. L.A. L. REV. 1295 (2008) (discussing the application of "naked" statistics to the preponderance of the evidence standard). Lay people are similarly hesitant. SANDERS, supra note 83, at 139-42 (summarizing research on willingness to infer liability from statistical data alone); Edward F. Wright et al., Factors Affecting the Use of Naked Statistical Evidence of Liability, 136 J. Soc. PSYCHOL. 677, 685 (1996) (finding that neither group discussion nor extended decision time overcame mock jurors' reluctance to use naked statistical evidence).

171. E.g., Brock, 874 F.2d at 310; see SANDERS, supra note 83, at 190 (noting that concern for consistency "resonates" in Bendectin opinions). See generally Walker, supra note 2, at 1108-09 (arguing that, if statistical evidence shows that causation is true only in a certain percentage of cases, the objective of "equal treatment of similar evidence" necessarily implies that adjudicative errors will not be equally distributed).

172. Sanders, supra note 20 , at 1040 . In theory, courts might apply claim 
Several such categories of cases, including the Bendectin cases, have been described as "situations where subsequent scientific study has refuted prior legal determinations of general causation." ${ }^{173}$ These situations have encouraged calls for limiting or eliminating the tort system's role in determining toxic tort causation questions, which reflect a loss in "confidence in the legal system ... when hindsight shows that liability was imposed on an entity that did not 'cause' another's harm using any meaning of the word." ${ }^{174}$ Might the desire to avoid this loss of legitimacy justify the false negative asymmetry?

To the extent that the loss of legitimacy results simply because erroneous adjudication sometimes occurs, ${ }^{175}$ preferring one type of error over another does not seem justified. There is no reason to expect confidence in the legal system to deteriorate any less if compensation is denied and hindsight shows that toxic exposure probably caused the illness after all. The law promises redress for wrongful injury. A demonstrable failure to keep that promise has the flavor of betrayal, particularly if judges are perceived to have deprived deserving plaintiffs not just of financial recoveries, but of their day in court.

Here, too, it is no answer to say that the asymmetry is appropriate because the law must take the science as it finds it. In applying that principle, the courts decide how much or how little scientific evidence constitutes no legal evidence. The application may produce the false negative asymmetry, but does not provide a legitimacy-based justification for it.

preclusion to hold that general causation is established as a matter of law. In a few circumstances, courts have to some extent limited dispute of general causation. E.g., Hanford Nuclear Reservation Litig. v. E.I. DuPont, 292 F.3d 1124, 1137 (9th Cir. 2002) (noting scientific and legal authority recognizing that radiation can cause cancer at lowest doses); see Boston, supra note 50, at 293 (observing that by the mid-1970s, courts held as matter of law that asbestos causes mesothelioma). But the court's resolution of general causation is less useful to a plaintiff than to a defendant because each plaintiff must prove the extent of exposure and specific causation as well. See Hanford, 292 F.3d at 1134.

173. Klein, supra note 2, at 30 n.149.

174. Id. at 30. Professor Klein's article does not endorse the asymmetrical preference for false negatives or proposals to eliminate the role of tort law, but argues for strong adherence to sine qua non causation in toxic tort cases. Id.

175. See Walker, supra note 2, at $1081 \mathrm{n} .13$ ("[G]rounding the legitimacy of judicial action" is one justification for law's "goal of discovering truth.").

176. See generally Marc Galanter, Why the "Haves" Come Out Ahead: Speculations on the Limits of Legal Change, 9 LAW \& SOC'Y REV. 95, 137 (1974) (noting that "have-nots" often litigate for symbolic reasons). 
It is true, however, that the two types of errors are not equally visible. Incorrect imposition of liability is easily observed if later scientific inquiry refutes the accuracy of earlier judgments. It becomes even more obvious if a product's sellers take action apparently in response to the liability, such as removing a drug from market. ${ }^{177}$ By contrast, harm actually caused by toxic exposures, erroneously left unremedied, may easily be missed. The verdicts and judicial opinions in the defense's favor themselves become known, at least to the bar and perhaps to the public, but the consequential effects of false negative causation holdings are harder to detect. Potential plaintiffs may not pursue claims, potential plaintiffs' counsel may not accept cases, and even further scientific inquiry into the alleged causal relation may be inhibited. ${ }^{178}$

Relatively invisible errors are unlikely to affect the perceived legitimacy of the judicial process as much as readily visible errors. On the other hand, false negative errors in toxic causation cases can tend to reinforce perceptions of the legal system as favoring the interests of large corporations at the expense of individual human beings, undermining the system's claim of equal justice under law. ${ }^{179}$

The law's truth-seeking function vitally supports the legitimacy of the rule of law. Minimizing error is a noble goal. But the legitimacy rationale seems an insufficient justification for asymmetrical error avoidance.

177. See GreEN, supra note 83, at 180-87 (describing withdrawal of Bendectin from the market and known or hypothesized considerations relevant to withdrawal decision).

178. See CRANOR, supra note 142, at 6-7 (noting inhibitory effect of judicial screening of expert testimony on "plaintiffs' realistic access to the law"); GREEN, supra note 83, at 332 (noting that litigation made Bendectin a "hot topic" among researchers, promoting scientific investigation); Stephen Breyer, REFERENCE MANUAL On SCIENTIFIC EVIDENCE, Introduction, at 1, 3 (Fed. Judicial Center ed., 2d ed. 2000) (acknowledging that incorrect denials of compensation "discourage other similarly situated individuals from even trying to obtain compensation").

179. McGarity, supra note 14, at 26 (arguing that one could view the imposition of a relative risk threshold greater than two "as a policy of shielding manufacturers of dangerous products from accountability through tort law."). 


\section{The Welfare Rationale: Courts as Policy Makers}

Justice Breyer's concurring opinion in Joiner provided a glimpse of another concern that could underlie the false negative asymmetry. Justice Breyer acknowledged that "scientific evidence implicates some chemicals as potential causes of some cancers," which was the essence of the allegation at issue in Joiner. ${ }^{180} \mathrm{He}$ worried, however, that "modern life, including good health as well as economic well-being, depends upon the use of artificial or manufactured substances...."181 Therefore, he reasoned, stringent judicial evidentiary gatekeeping was needed to "help assure that the powerful engine of tort liability, which can generate strong financial incentives to reduce, or to eliminate, production, points towards the right substances and does not destroy the wrong ones." 182

On its face, Justice Breyer's exhortation to trial judges seems neutral, pleading for accuracy in both positive and negative assessments of causal attribution. The real emphasis, however, could not be plainer:

In Justice Breyer's view, a legal decision that a product is harmful when science is not yet certain presents greater policy problems than the alternative of allowing continued marketing and barring the courthouse door to ill people whose claims of causation may in fact later be widely embraced by the scientific community. ${ }^{183}$

180. Gen. Elec. Co. v. Joiner, 522 U.S. 136, 148 (1997). Mr. Joiner alleged that exposure to PCBs, furans and dioxins hastened his development of lung cancer. Id. at 139 .

181. Id.

182. Id. at 148-49; see also Metro-North Commuter R.R. v. Buckley, 521 U.S. 424, 434-35 (1997) (holding in Justice Breyer's majority opinion was that a railroad worker exposed to asbestos could not use contact with asbestos as basis of claim for emotional distress damages, in part because of frequency with which Americans are exposed to carcinogens, and expressing concerns about higher prices that would result if such claims were allowed).

183. Finley, supra note 116, at 345. Other scholars have read Justice Breyer's concurrence similarly. E.g., David E. Bernstein, Asbestos Litigation E Tort Law: Keeping Junk Science Out of Asbestos Litigation, 31 PePP. L. REV. 11, 24-26 (2003); Michael H. Gottesman, From Barefoot to Daubert to Joiner: Triple Play or Double Error?, 40 ARIZ. L. REV. 753, 761 (1998); Stephan Landsman, The Jury's Role in Administering Justice in the United States: Of Mushrooms and Nullifiers: Rules of Evidence and the American Jury, 21 ST. LouIs U. PuB. L. REv. 65, 69 (2002); McGarity, supra note 13, at 41; Julie A. Seaman, Triangulating Testimonial Hearsay: The Constitutional Boundaries of Expert Opinion Testimony, 96 GEO. L.J. 827, 874-75 (2008). 
Justice Breyer stressed that in cases "where testimony about general risk levels in human beings or animals is offered to prove individual causation" ${ }^{\prime 184}$ - the paradigmatic toxic tort situation-it was particularly "essential" ${ }^{185}$ for trial courts to exercise their power to control the introduction of expert evidence, even if doing so might require "subtle and sophisticated determinations about scientific methodology." ${ }^{286}$ This is very nearly an explicit endorsement of the false negative asymmetry; ${ }^{187}$ it has been applied to that effect.

In Tamraz v. Lincoln Electric Co., ${ }^{188}$ a divided panel of the Sixth Circuit reversed and remanded a plaintiff's judgment entered on a jury verdict. The appellate court held that the trial judge had abused her discretion in admitting the testimony of one of plaintiff's experts who opined that manganese in welding fumes caused the plaintiff's illness. ${ }^{189}$ The majority acknowledged that if plaintiff "does not [prevail on retrial], yet it turns out ten years from now that manganese causes his disease, that result will seem unfair. But the alternative route-allowing the law to get ahead of science-would be just as unfair." ${ }^{290}$ Why? Citing Justice Breyer's Joiner concurrence, the court explained: because it "would destroy jobs and stifle innovation unnecessarily." ${ }^{191}$

184. Joiner, 522 U.S. at 148 (Breyer, J., concurring).

185. Id. at 149 .

186. Id. at 147.

187. See Gass v. Marriott Hotel Servs., Inc., 558 F.3d 419, 437 (6th Cir. 2009) (Boggs, J., dissenting) (construing Justice Breyer's concern about the "powerful engine of tort liability" as a warning that "it is too easy to charge an uncommon harm to the presence of a mysterious substance").

188. 620 F.3d 665 (6th Cir. 2010).

189. Id. at 667 .

190. Id. at $677-78$.

191. Id. at 678. It is interesting that the court equated reduced social welfareless innovation and lost jobs for unidentified individuals - with "unfairness" similar to the injustice of denying a valid claim for physical harm done to a particular plaintiff. The majority also invoked the slaves-of-science rationale, describing "the alternative route" as "allowing the law to get ahead of science." Id. at 677-78. The dissent argued that there was plenty of science for the law to chew on; the causal link in question "was certainly the subject of valid scientific debate and publication" but the majority demanded excessive scientific "finality." Id. at 68384 (Martin, J., dissenting). The case was a bellwether trial in multi-district litigation involving hundreds of cases. Id. at 667; see In re Welding Fume Prods. Liab. Litig., 526 F. Supp. 2d 775, 777 (N.D. Ohio 2007). This procedural posture may have influenced the stringency of the appellate court's view of the causation evidence. See Boston, supra note 50, at 363-83 (arguing that courts should be more stringent in mass exposure cases). 
Justice Breyer returned to this theme in his extra-judicial writings as well. A significant portion of his introduction to the influential Reference Manual on Scientific Evidence dwells on toxic tort causation. $^{192}$ Although here, too, Justice Breyer acknowledges that false negative decisions have adverse consequences, the façade of neutrality again is easily pierced:

A decision wrongly denying compensation in a toxic substance case, for example, can not only deprive the plaintiff of warranted compensation but also discourage other similarly situated individuals from even trying to obtain compensation and encourage the continued use of a dangerous substance. On the other hand, a decision wrongly granting compensation, although of immediate benefit to the plaintiff, can improperly force abandonment of the substance. Thus, if the decision is wrong, it will improperly deprive the public of what can be far more important benefits-those surrounding a drug that cures many while subjecting a few to less serious risk, for example. ${ }^{193}$

Who would want to "force abandonment" (as opposed to merely internalizing externally-imposed costs) of a drug that "cures many" (presumably of a fatal or deadly disease) to compensate "a few" (the unlucky who must pay the price of progress) for a "risk" (that presumably may not come to pass, though the existence of an actual plaintiff would suggest otherwise) that is "less serious" (perhaps little more than a nuisance)? Justice Breyer's conclusion fairly leaps from his imagery. Whether it fairly fits his data is another question.

The influence of the self-consciously political-and controversial—crusade against so-called "junk science" is manifest in Justice Breyer's work. ${ }^{194}$ But, as we are often reminded, courts decide particular concrete cases. ${ }^{195}$

192. Breyer, supra note 178, at 3-7.

193. Id. at 3-4. For Justice Breyer's views on the risks of environmental exposures and government regulation thereof, see generally STEPHEN BREYER, BREAKING THE ViCIOUS CiRCLE (1993).

194. See Breyer, supra note 178, at 4 (citing Peter W. Huber, Galileo's Revenge: Junk Science In the Courtroom 54 (1991)). For a critique, see Kenneth J. Chesebro, Galileo's Retort: Peter Huber's Junk Scholarship, 42 AM. U. L. REv. 1637 (1993).

195. E.g., Brock v. Merrell Dow Pharms., Inc., 874 F.2d 307, 315 (5th Cir. 1989), modified on reh'g, 884 F.2d 166 (5th Cir. 1989) (“[G]eneral and abstract formulations" of the standards for directed verdicts or judgments notwithstanding 
So despite all the case law and commentary published since Daubert and Joiner, it is helpful to go back to these beginnings and consider the particular toxic tort cases the Supreme Court saw and the role these cases played in promoting the false negative asymmetry that is subliminal in Daubert, evident in the majority opinion in Joiner, and overt in Justice Breyer's Joiner concurrence.

Daubert was a Bendectin case. By the time it reached the Supreme Court, courts had begun their concerted effort to force an end to Bendectin litigation, primarily because extensive epidemiologic research had failed to associate pregnant women's Bendectin consumption with a statistically significant increased risk of any particular birth defect. ${ }^{196}$ This backdrop likely explains the Supreme Court's decision to include, alongside its holding that the science supporting an expert opinion need not be "generally accepted" to be admissible, lengthy dicta setting out the nowfamiliar non-exclusive list of "factors [that] will bear on the inquiry." ${ }^{197}$ Lower courts received and understood this multiplex signal. As one district judge put it just a few weeks after the Supreme Court handed down Daubert, the decision "kill[ed] Frye and then resurrect[ed] its ghost." ${ }^{198}$

In Daubert itself, the Ninth Circuit on remand evaluated the proffered testimony of each of the plaintiffs' experts and determined that it had to be excluded as a matter of law-that for a trial judge to admit it would be an abuse of discretion. ${ }^{199}$ The court's analysis of the testimony's reliability emphasized that the plaintiffs' experts' efforts did not spring from pre-existing

the verdict "lose much of their usefulness . . . when we attempt to apply them to the concrete factual situation at hand.").

196. SANDERS, supra note 83, at 190 (noting that the judiciary became convinced that any plaintiff verdict was wrong). Much of this research developed in response to the litigation. GREEN, supra note 83, at 332.

197. Daubert v. Merrell Dow Pharms., Inc., 509 U.S. 579, 593 (1993).

198. In re Joint E. \& S. Dist. Asbestos Litig., 827 F. Supp. 1014, 1033 (S.D.N.Y. 1993), aff'd in part, rev'd in part sub nom. Maiorana v. U.S. Mineral Prod. Co., 52 F.3d 1124 (2d Cir. 1995) (citing Frye v. United States, 293 F. 1013, 1014 (D.C. Cir. 1923)).

199. Daubert v. Merrell Dow Pharms., Inc., 43 F.3d 1311, 1315, 1321-22 (9th Cir. 1995). Because the Dauberts had appealed from a summary judgment, the Ninth Circuit would "affirm the summary judgment only if, as a matter of law, the proffered evidence would have to be excluded at trial." Id. at 1315. To help district judges understand how they should tilt in future similar cases, the court of appeals emphasized that even if the evidence were "not per se inadmissible, the district court on remand would nevertheless have discretion to reject it." $I d$. (emphasis added). 
campaigns of original research independent of litigation and had not been published in peer-reviewed journals. Failing that, the Ninth Circuit held that the experts needed to, but did not, "point to some objective source ... to show that they have followed the scientific method, as it is practiced by (at least) a recognized minority of scientists in their field."200

Despite this strong implication that the plaintiffs' experts would fail the Supreme Court's reliability test, the panel that decided Daubert on remand excluded only one of plaintiffs' experts for that reason. ${ }^{201}$ The others, the court acknowledged, might be able to provide the needed "objective, independent" evidence of reliability if given the chance to do so on remand to the district court. $^{202}$ For example, a witness who testified about teratogenicity testing in animals might be able to explain why extrapolation from the animal studies to humans is valid. ${ }^{203}$ The Ninth Circuit did not give them the chance.

Instead, the court prohibited them from testifying for lack of "fit," the second requirement enunciated by the Supreme Court. ${ }^{204}$ Why did their testimony not "fit?" Because none of them would testify that epidemiologic evidence showed Bendectin more than doubled the risk of plaintiff's birth defect. ${ }^{205}$ In effect, the Ninth Circuit held that even assuming the plaintiffs' experts' testimony could establish general causation, without proof of relative risk greater than two, the plaintiffs could not establish specific causation. $^{206}$ And that, the Ninth Circuit held, made all of the testimony not just insufficient but inadmissible ${ }^{207}$-an early example of the commingling of these two theoretically separate standards.

200. Id. at 1319. The court described "(at least) a recognized minority" as a relaxation of the general acceptance test. Id. at 1319, n.11. But the court's indicia of reliability track closely with general acceptance.

201. That expert opined that Bendectin caused the plaintiff's particular birth defect. Id. at 1319. The Ninth Circuit held that such an opinion could not be scientifically reliable. $I d$. at 1319.

202. Id. at 1320 .

203. Id. The Ninth Circuit had to consider this possibility because the parties and the district court had proceeded under the newly-invalidated Frye test; plaintiffs argued that the appellate court should remand for development of a record applying the new test. Id. at 1314-15.

204. Id. at 1320 .

205. Id. at 1320-21.

206. Id. at 1322 ("[W] hat plaintiffs must prove is not that Bendectin causes some birth defects, but that it caused their birth defects.”).

207. Id. 
There can be little doubt that the Bendectin cases powerfully influenced judicial perceptions of claims alleging that serious but difficult-to-trace illnesses were caused by exposure to toxic substances. $^{208}$ Courts rejecting Bendectin claims ${ }^{209}$ increasingly announced the rigid and strict rules that together produce the false negative asymmetry, culminating in the Texas Supreme Court's Havner opinion ${ }^{210}$ handed down just a few months before the United States Supreme Court decided Joiner. Although these cases were decided in the factual context of Bendectin claims, by and large the appellate courts made no effort to restrict the legal rules they announced to that context. ${ }^{211}$

Thus, by the time the Supreme Court decided Joiner, the Bendectin cases and the plaintiffs' experts in those cases had taken on a symbolic, representative significance. Joiner, of course, was not about Bendectin. The plaintiff, Robert Joiner, alleged that exposure to PCBs had promoted his lung cancer. ${ }^{212}$ Unlike the Bendectin plaintiffs, Joiner did not confront a wall of large epidemiologic studies that failed to show an increase in risk associated with exposure. Instead, his experts tried to rely on epidemiologic studies, together with animal studies, to establish

208. See Restatement (ThiRd) of Torts: Liab. For Physical and Emotional HARM $\$ 28 \mathrm{cmt}$. c (2010) (noting that the Agent Orange and Bendectin cases "led some courts to distrust juries' ability to resolve cases based on conflicting expertopinion evidence"); GrEEN, supra note 83, at 307-10.

209. The history of reported Bendectin decisions is sketched in Merrell Dow Pharms., Inc. v. Havner, 953 S.W.2d 706, 709-11 (Tex. 1997), and detailed in SANDERS, supra note 83, at 146-49, 157-58.

210. Havner, 953 S.W.2d 706 (Tex. 1997).

211. E.g., id. at 717 ("[W]e are persuaded that properly designed and executed epidemiological studies may be part of the evidence supporting causation in a toxic tort case and that there is a rational basis for relating the requirement that there be more than a 'doubling of the risk' to our no evidence standard of review and to the more likely than not burden of proof." (emphasis added)); see also supra note 61 and accompanying text. Although some courts later tried to limit the generality of some of the holdings in Bendectin cases, they rarely suggested that the holdings applied only to Bendectin claims. E.g., Taylor v. Bristol-Myers Squibb Co., No. 5:01-CV-166-C, 2004 LEXIS 30805, at*3-4 (N.D. Tex. Sept. 15, 2004) (treating Havner as limited to sufficiency, rather than admissibility, of evidence). When a panel of the Fifth Circuit tried to do so, the en banc court rejected the attempt. Christopherson v. Allied-Signal Corp., 902 F.2d 362 (5th Cir. 1990), superseded, 939 F.2d 1106 (1991) (en banc); see also Cano v. Everest Minerals Corp., 362 F. Supp. 2d 814, 822 (W.D. Tex. 2005) ("Havner. . . spoke generally about the use of epidemiological evidence . . . and the Court does not read the opinion to limit those principles solely to the Bendectin context.").

212. Joiner v. General Elec. Co., 864 F. Supp. 1310, 1314 (N.D. Ga. 1994), rev'd, 78 F.3d 524 (11th Cir. 1996), rev'd, 522 U.S. 136 (1997). 
causation. $^{213}$

Writing for a majority that included Justice Breyer, Chief Justice Rehnquist examined, one by one, scientific studies on which Joiner's experts relied and opined that some defect made the study inadequate to support the inference of causation to which the expert was prepared to testify. ${ }^{214}$ Therefore, the Court held, the district judge had not abused her discretion in applying Daubert to preclude the experts' testimony. ${ }^{215}$ This approach elicited dissent from Justice Stevens, ${ }^{216}$ but the majority was unmoved. The opinion of the Court stated, "[a] court may conclude that there is simply too great an analytical gap between the data and the opinion proffered." ${ }^{217}$ As support for that proposition, the Court cited the one and only toxic tort case (besides Daubert) that it deigned to mention: Turpin v. Merrell Dow Pharmaceuticals, another Bendectin case. $^{218}$

Joiner's direct borrowing from Turpin $^{219}$ suggests that the history and notoriety of the Bendectin litigation influenced Chief Justice Rehnquist's migration from his cautious position in Daubert to the aggressive, arguably unnecessary ${ }^{220}$ attack on Joiner's experts' reasoning. Turpin also prefigured Justice Breyer's concerns about the harm of wrongful conclusions of causation.

The Turpin court, affirming the exclusion of expert testimony based on animal studies, took pains to explain that even if (as plaintiffs' experts said) such studies showed Bendectin had the "capacity" to cause developmental defects, they did not support an inference that Bendectin caused such defects in humans. Quoting a "recognized text on teratology," the court noted that "virtually all

213. The epidemiologic evidence was not as strong as plaintiff might have liked; one of plaintiff's experts described a study conducted in Japan as "suggestive but not convincing." Id. at 1326.

214. Joiner v. General Elec. Co., 522 U.S. 136, 146-47 (1997).

215. Id. at 143 .

216. Id. at 150 (Stevens, J., dissenting in part). Commentators later criticized the majority approach as well. See supra note 122 and accompanying text.

217. Joiner, 522 U.S. at 146.

218. Id. (citing Turpin v. Merrell Dow Pharms., Inc., 959 F.2d 1349, 1360 (6th Cir. 1992)).

219. Turpin, 959 F.2d at 1360-61 ("The analytical gap between the [animal study] evidence presented and the inferences to be drawn on the ultimate issue of human birth defects is too wide. Under such circumstances, a jury should not be asked to speculate on the issue of causation.").

220. See Joiner, 522 U.S. at 151 (Stevens, J., dissenting in part) (arguing for remand to court of appeals for application of correct standard of review of district court's admissibility decision). 
drugs and a great range of chemicals" could harm embryos "under appropriate laboratory conditions.",221 This might have been sufficient to support the argument that the inference was unjustified, because it is presumably not the case that "virtually all drugs and a great range of chemicals" are human teratogens at ordinary exposure doses. ${ }^{222}$

The court, however, did not stop there. "The author concludes," the court continued, "that to "eliminate drugs and chemicals because they can be shown to be embryotoxic at high dosage would be unacceptable' because to do so 'would eliminate most drugs and many useful chemicals upon which modern society depends heavily.",223 Thus plaintiffs' experts' causal inference must also be rejected because the social cost of accepting it is simply too high. To allow such testimony would turn the "powerful engine" on too many valuable products. ${ }^{224}$

This explicit social calculus concurs implicitly in the generally accepted Bendectin narrative. Bendectin's manufacturer withdrew the drug from the United States market in 1983, relatively early in the life history of both litigation about the drug and of epidemiologic research into whether Bendectin was teratogenic. ${ }^{225}$ Given the consensus that Bendectin did not cause the birth defects of which it was suspected, and the lack of any approved available substitute for it in treating pregnancy-related nausea, many commentators have lamented the social costs imposed by Bendectin's unavailability. ${ }^{226}$ Nevertheless, and irrespective of

221. Turpin, 959 F.2d at 1359 (quoting James Wilson, Current Status of Teratology, in HANDBook of Teratology 60 (J. Wilson \& C. Fraser eds., 1977)).

222. Then again, one never knows, because no one knows the cause of the vast majority of birth defects. See Lynch v. Merrell-Nat'l Labs., Div. of RichardsonMerrell, Inc., 830 F.2d 1190, 1193 (1st Cir. 1987). Perhaps, instead of being the cruel caprice of a stochastic universe, many of those idiopathic birth defects result from very small, effectively unmeasurable, teratogenic effects of one or another ubiquitous component of the human environment.

223. Turpin, 959 F.2d at 1359 (quoting James Wilson, supra note 221).

224. Even before Turpin, the Fifth Circuit had expressed the same concern in another Bendectin case. Brock v. Merrell Dow Pharms., Inc., 874 F.2d 307, 310 (5th Cir. 1989), modified on reh'g, 884 F.2d 166 (5th Cir. 1989) ("Appellate courts, if they take the lead in resolving those questions upon which juries will go both ways, can reduce some of the uncertainty which can tend to produce a sub-optimal amount of new drug development.").

225. GREEN, supra note 83, at 180-87.

226. E.g., James M. Sabovich, Petition Without Prejudice: Against the Fraud Exception to Noerr-Pennington Immunity from the Toxic Tort Perspective, 17 PenN. ST. ENVTL. L. REV. 1, 32 (2008). 
whether the Bendectin narrative is subject to challenge, ${ }^{227}$ Bendectin-as-prototype is an assumption, not an established fact. ${ }^{228}$

To Bendectin's thesis, DES is the antithesis. DES, far from being a vital and irreplaceable medicine, was pretty much useless for its intended purpose. ${ }^{229}$ It caused (unlike Justice Breyer's hypothetical drug hounded from the market) not merely a risk of an annoyance, but at least hundreds of cases of cancer. ${ }^{230}$

It bears repeating that in the early 1980s there was reason to worry about Bendectin. The animal studies and chemical structure information that some experts used to draw inferences about Bendectin's likely teratogenicity were not invented or fanciful. ${ }^{231}$ Subsequent human epidemiologic studies repeatedly failed to confirm those inferences. It does not follow that such inference is inherently improper. Nor does it follow that the strength of such inferences is the same for suspected carcinogens as for suspected teratogens, or for one type of cancer as another, or for one substance as another.

Of course some substances suspected of causing disease are later shown not to do so, but other substances cause disease while the evidence of their toxicity accrues. The evidence that cigarette smoking causes lung cancer accumulated slowly for decades, ${ }^{232}$ while tobacco companies argued that animal studies and other

227. See GREEN, supra note 83, at 336-37 (noting that Bendectin may have been less effective than claimed, that doctors may have prescribed Bendectin inappropriately, and that substitute medications were available after Bendectin's manufacturer withdrew the drug from the market).

228. Some courts substitute the breast implant litigation as the prototype. See Tamraz v. Lincoln Elec. Co., 620 F.3d 665, 678 (6th Cir. 2010).

229. Sarina Schrager \& Beth E. Potter, Diethylstilbestrol Exposure, 69 Am. FAMILY PHYSICIAN 2395, 2395 (2004) (noting data published in 1953 showed DES was ineffective for preventing pregnancy complications, but that it was prescribed for this purpose at least until 1971, when published data revealed the association of DES with vaginal clear cell adenocarcinoma).

230. CNTRS. FOR Disease CONTROL \& Prevention, DES Update, http://www.cdc.gov /des/consumers/download/cdc_des_update.pdf (stating risk of developing vaginal clear adenocarcinoma before menopause is "virtually non-existent" absent in utero exposure to DES, which increases risk 40 times) (last visited Apr. 9, 2011); Ralph I. Horwitz et al., Clear Cell Adenocarcinoma of the Vagina and Cervix: Incidence, Undetected Disease, and Diethylstilbestrol, 41 J. CliniCAl EPIDEMiology 593, 593, 597 (1987) (noting more than 500 cases of clear cell adenocarcinoma then known to exist, but that previously reported incidence rates "greatly underestimate the true occurrence of the cancer").

231. SANDERS, supra note 83, at 63 ("At the end of 1984 one would have concluded that the in vivo research cast doubt on the safety of Bendectin.").

232. Allan M. Brandt, The Cigarette Century 123-57, 211-17 (2007) (describing research from the 1920s to 1960s). 
experiments failed to provide scientific proof of the link between cigarette smoking and lung cancer. ${ }^{233}$ Similarly, the link between asbestos and several diseases, now so widely accepted, took time to prove and was disputed for years. ${ }^{234}$

The toxicity of lead has been known for centuries, ${ }^{235}$ but proof of lead's effects at low levels and the link between specific products and exposure routes developed only slowly. For example, into the 1970 s, the lead industry insisted that airborne lead had not been

233. See, e.g., Green v. Am. Tobacco Co., 391 F.2d 97, 103 (5th Cir. 1968) (describing how, on retrial limited to issue of whether defendant's cigarettes were fit and wholesome for human use, defendant introduced testimony that cause of cancer was unknown), overruled on reh' $g$ en banc, 409 F.2d 1166 (5th Cir. 1969); Green v. Am. Tobacco Co., 304 F.2d 70, 72 (5th Cir. 1962) (describing battle of experts at trial on question of whether cigarette smoke caused plaintiff's lung cancer); see also, e.g., Ross v. Philip Morris \& Co., 328 F.2d 3, 8-9 (8th Cir. 1964) (describing defendant's argument that plaintiff had not submitted sufficient evidence of causation to reach the jury); Lartigue v. R.J. Reynolds Tobacco Co., 317 F.2d 19, 22-3 (5th Cir. 1963) (describing defendant's argument at trial for lack of causal connection between smoking and plaintiff's cancer and that plaintiff's other medical conditions, such as rheumatism, caused cancer); Pritchard v. Liggett \& Myers Tobacco Co., 295 F.2d 292, 296 (3d Cir. 1961) (describing defendant's argument that plaintiff's experts' causation opinions "should have no validity" because of lack of proof of their general acceptance). Even in the 1980s, expert witnesses and tobacco executives testified that despite statistical association showing cigarette smoking is a risk factor for lung cancer, it had never been proven to be a cause of lung cancer. See BRANDT, supra note 232, at 341, 343 (quoting testimony). See generally Daniel Givelber, Cigarette Law, 73 IND. L.J. 867, 894-95 (1998) (stating that for individual plaintiff smokers, causation claims would still be vulnerable to attack because of group-based nature of the evidence); Robert L. Rabin, A Sociolegal History of the Tobacco Tort Litigation, 44 STAN. L. REV. 853, 858 (1992) (from outset of litigation against cigarette companies, "industry hotly contested the causal linkage between smoking and lung cancer."); id. at 860 (industry has never conceded causation even though in earliest cases juries generally found causation).

234. See Paul Brodeur, Outrageous Misconduct 112-27 (Pantheon Books 1985) (describing efforts of asbestos industry to suppress or impugn evidence of health effects accumulating during 1920s through 1940s); W.C. Hueper, Occupational and Nonoccupational Exposures to Asbestos, 132 ANNALS N.Y. ACAD. SCI. 184, 184 (1965) (stating that despite three decades of increasing amount of epidemiologic, clinical, and pathologic evidence linking asbestos to lung cancer and mesothelioma, "some commercially interested parties and their medical guardians and protectors still prefer . . . to deny the existence of these dangerous and usually fatal sequelae of a respiratory contact with asbestos dust."); $i d$. at 192 (noting "highly controversial negative results" of an "industry-dominated" Canadian epidemiologic study).

235. Agency for Toxic Substances \& Disease Registry (ATSDR), U.S. Dep't of Health \& Human Servs., Toxicological Profile for Lead 21 (2007), available at http:/ / www.atsdr.cdc.gov/toxprofiles/tp13.pdf. 
shown to be a human health hazard. ${ }^{236}$ When the Environmental Protection Agency (EPA) proposed phasing down the amount of lead in gasoline, it could not be certain that reducing this airborne exposure source would reduce the concentration of lead in children's blood. ${ }^{237}$ Thoroughly convincing proof came only after the regulation went into effect over a stiff industry challenge, essentially allowing the EPA to conduct a nationwide epidemiologic experiment. ${ }^{238}$ Newer findings have pushed the supposedly "safe," or at least officially acceptable, blood level of lead steadily downward. ${ }^{239}$

Many of the above examples have in common industry's persistent efforts to question, minimize, deny, and at worst conceal the health effects of a product. But sometimes, even without profit motive, studies that seem to absolve alleged causes have been proven wrong. For example, after concern emerged about lead in drinking water in some homes in Washington, D.C., the Centers for Disease Control and Prevention (CDC) rushed to publish a reassuring report, which understated the effect of high lead concentrations in drinking water on the blood lead levels of children, based on preliminary data that had not undergone rigorous review. ${ }^{240}$ The CDC did not acknowledge the error for six

236. Christian Warren, Brush With Death 220 (Johns Hopkins Univ. Press 2000) (quoting 1970 legislative testimony by Lead Industries Association trade executive director, John Kimberly).

237. See Ethyl Corp. v. EPA, 541 F.2d 1, 25 (D.C. Cir. 1976) ("The problems faced by EPA in deciding whether lead automotive emissions pose a threat to the public health highlight the limitations of awaiting certainty" before regulating); $i d$. at 47 ("The evidence did not always point in one direction. . . ."); id. at 73 ("Implicit in the administrative record . . . is the recognition by EPA that available scientific data did not provide a clear and certain basis for reaching the statutorily mandated conclusion .....") (Wilkey, J., dissenting); see id. at 38-46 (outlining information in the administrative record as well as the information's limitations).

238. Small Refiner Lead Phase-Down Task Force v. EPA, 705 F.2d 506, 529 (D.C. Cir. 1983); see Jamie Lincoln Kitman, 8,500 Years of Lead, 79 Years of Leaded Gasoline, The NATion (Mar. 20, 2000), http://www.mindfully.org/Pesticide/LeadHistory.htm.

239. In the 1970 s, blood lead levels above thirty micrograms per deciliter were considered "excessive." Small Refiner Lead Phase-Down Task Force, 705 F.2d at 527. Today, federal authorities consider children to have elevated blood lead if the concentration is above ten micrograms per deciliter, but acknowledge that lower levels have been associated with neurobehavioral effects and there appears to be no threshold below which lead is not neurotoxic. See ATSDR, supra note 235, at 16, 23; see also CRANOR, supra note 142, at 278 (describing similar development of evidence of the toxicity of low-level benzene and arsenic).

240. Majority StafF of the Subcomm. On Investigation \& Oversight of the Comm. on Sci. \& Tech., U.S. House of Representatives, A Public Health 
years, during which time, to all appearances, the "best" scientific evidence indicated that the lead in the water was no cause for concern. ${ }^{241}$

Even in the case of drugs, which-unlike most substancesundergo advance testing for safety, evidence that accumulates after marketing regularly reveals harmful effects not previously detected. ${ }^{24}$ The slowly building case that led to recent restrictions on the use of the diabetes drug rosiglitazone is a case in point. ${ }^{243}$ In August 2007, based on adverse event reporting, the Food and Drug Administration (FDA) required a boxed warning about cardiac risks of the drug. ${ }^{244}$ Just three months later, the FDA strengthened

Tragedy: How Flawed CDC Data and Faulty Assumptions Endangered ChildREN's HEALTH IN THE NATION's CAPITAL 33-35 (2010), available at http://democrats.science.house.gov/Media/file/Commdocs/hearings/2010/Ove rsight/20may/Staff\%20Report_DC\%20Lead_5.20.10.pdf.

241. Robert McCartney, A Champion of the Truth About Lead-Tainted Tap Water, WASH. Post, May 23, 2010, at C1, C3 (noting that CDC issued its report in 2004 and issued corrective notice in 2010, after publication in 2009 of independent research demonstrating that original report understated risks). The examples of lead in air and water relate to proof that an environmental exposure produced higher body burdens rather than proof that a received dose caused disease, but the situations are analogous. In any claim for damages resulting from exposure to airborne or water-borne lead, the connection between the environmental level and the body burden would be a link in the causal chain. See Cranor, supra note 142, at 35 (describing the causation element required for toxic tort suits).

242. The complexity of drugs' biological activity and the difference between populations in controlled clinical trials and the range of patients who may take a drug after approval make it "impossible to know everything about a drug at the point of approval .... Thus, the understanding of a drug's risk-benefit profile necessarily evolves over the drug's lifecycle." COMM. ON THE ASSESSMENT OF THE U.S. Drug Safety Sys, Inst. of Med. of The Nat'L Acad., The Future of Drug Safety: Promoting \& Protecting the Health of the Public 2 (Alina Baciu et al. eds., 2007), available at http://books.nap.edu/openbook.php?record_id=11750. For a description of the drug approval process and post-marketing monitoring, see id. at 31-51 (approval), 51-9 (post-approval). For recent amendments to those processes, see Food and Drug Administration Amendments Act of 2007, Pub. L. No. 110-85 (codified as amended at 21 U.S.C. \$ 301). See also GrEEN, supra note 83, at 52-3 (noting that when General Accounting Office studied 198 approved drugs, more than half had serious risks not detected prior to approval); Thomas O. McGarity, Corporate Accountability for Scientific Fraud: Ketek and the Perils of Aggressive Agency Preemption, 58 EMORY L.J. 287, 293 (2008) (noting that preapproval testing is "statistically incapable of detecting side effects that occur relatively rarely, have long latency periods," or occur in vulnerable sub-populations not studied).

243. Rosiglitazone is better known by one of its trade names, Avandia. See Index to Drug-Specific Information, U.S. FOOD \& DRUG ADMIN., http://www.fda.gov/Drugs /DrugSafety/PostmarketDrugSafetyInformationforPatientsandProviders/UCM111 085\#Z (last visited Jan. 24, 2011).

244. Manufacturers of Some Diabetes Drugs to Strengthen Warning on Heart Failure 
the warning based on a meta-analysis of existing epidemiologic data. $^{245}$ In August 2009, the FDA received data from a long-term clinical study of the drug, ${ }^{246}$ and in September 2010, FDA relied on that data to "significantly restrict[]" the use of rosiglitazone. ${ }^{247}$ Other well-known examples include the cardiac and breast cancer risks associated with hormone therapy for menopausal women, which had been prescribed for decades, ${ }^{248}$ and the cardiac risk of widely prescribed non-steroidal anti-inflammatory drugs. ${ }^{249}$

Risk, U.S. FoOD \& DRUG ADMIN. (Aug. 14, 2007), http://www.fda.gov/NewsEvents /Newsroom/PressAnnouncements/2007/ucm108966.htm.

245. Janet Woodcock, FDA Press Conference on the Update to the Existing Box Warning on Avandia (Nov. 14, 2007) (transcript available at http://www.fda.gov /downloads/NewsEvents/Newsroom/MediaTranscripts/UCM122282.pdf).

246. FDA Drug Safety Communication: Ongoing Review of Avandia (Rosiglitazone) and Cardiovascular Safety, U.S. FoOD \& DRUG Admin. (Feb. 22, 2010), http:/ /www.fda.gov /Drugs/DrugSafety/PostmarketDrugSafetyInformationforPatientsandProviders /ucm201418.htm.

247. U.S. FoOd \& Drug Admin., HHS FDA: Briefing on Avandia (Sept. 23, 2010) (statement of FDA Commissioner Margaret Hamburg), http://www.fda.gov/Drugs/DrugSafety/PostmarketDrugSafetyInformationforPati entsandProviders/ucm227934.htm. The New York Times reported that the drug's manufacturer had not disclosed the results of a 1999 study suggesting that the drug carried more cardiac risk than a competing medication. Gardiner Harris, Diabetes Drug Maker Hid Test Data, Files Indicate, N.Y. TIMES, July 13, 2010, at A1.

248. Elizabeth Barrett-Connor, Book Review, 357 New ENG. J. MED. 1670, 1670 (2007) (reviewing Elizabeth Siegel Watkins, The Estrogen Elixir: A History of HORMONE REPLACEMENT THERAPY IN AMERICA (2007) (describing history of prescription of hormone treatment)); Wulf H. Utian, Book Review, 118 J. Clin. InVEST. 392 (2008) (reviewing ElizABETH Siegel WATkins, The Estrogen EliXiR: A History of HORMONE REPLACEMENT THERAPY IN AMERICA (2007)), available at http://www.ncbi.nlm.nih.gov/pmc/articles/PMC2214716/ (describing 2002 Women's Health Initiative findings as "reversal of general medical opinion"). See generally Peter M. Ravdin et al., The Decrease in Breast-Cancer Incidence in 2003 in the United States, 356 NEw ENG. J. MED. 1670 (2007) (linking reduced rates of breast cancer to women's decreased use of hormone therapy after publicity surrounding 2002 findings); Press Release, National Institutes of Health, WHI Study Data Confirm Short-Term Heart Disease Risks of Combination Hormone Therapy for Postmenopausal Women (Feb. 15, 2010), available at http://www.nih.gov/news /health/feb2010/nhlbi-15.htm (describing study of hormone therapy and recent findings).

249. McDarby v. Merck \& Co., Inc., 949 A.2d 223, 229-48 (N.J. Super. Ct. App. Div. 2008) (describing results and manufacturer's depiction of post-approval studies showing increased risk of cardiovascular events in patients taking Vioxx as compared to other drugs); Rita Rubin, How Did Vioxx Debacle Happen?, USA TODAY, Nov. 12, 2004, http://www.usatoday.com/news/health/2004-10-12-vioxx-cover _x.htm (quoting an FDA official's acknowledgment that evidence of effects accumulated for several years before withdrawal of drug). See generally Press Release, U.S. Food \& Drug Admin., COX-2 Selective (Includes Bextra, Celebrex, and Vioxx) and Non-Selective Non-Steroidal Anti-Inflammatory Drugs (NSAIDs) (April 7, 2005), http://www.fda.gov/NewsEvents/Newsroom/PressAnnouncements 
The point is simply that detecting these causal relations is difficult, almost always post hoc, and frequently generates conflicting information. ${ }^{250}$ It is incorrect to assume that the socialwelfare arrow points to an assumption of "no causation" in every case in which the causal connection has scientific support but is still uncertain. ${ }^{251}$ Yet that is the assumption upon which rests the welfare justification of the false negative asymmetry. ${ }^{252}$ Good health and economic well-being depend, as Justice Breyer said, on all kinds of substances, ${ }^{253}$ some of which may be incorrectly suspected of causing disease; but good health and economic well-being may also warrant less (or no) production of substances that cause disease while serving purposes that are of limited benefit or that could easily, cheaply, and safely be achieved by other means.

Even taking a strictly utilitarian view of tort law, enforcing the false negative asymmetry on the causation element is a theoretically incoherent way to achieve efficient case outcomes. A product may cause disease even if it is, on balance, socially useful; its benefits may be weighed against its risks in determining whether marketing the product was negligent, whether the product was unreasonably dangerous, or whether a warning about the product was inadequate. ${ }^{254}$ Absent one of these bases for liability, a false positive causation finding cannot result in over-deterrence. If negligence

/2005/ucm108427.htm.

250. See Comm. On the Assessment of the US Drug SAFETy System, supra note 242, at 57 ("Rare is the story that builds as clearly and completely as one would like for making scientific evaluations and regulatory decisions."). Even as the FDA restricted use of rosiglitazone, the scientist who made the decision described the supporting evidence as "not robust or consistent." Memorandum from Janet Woodcock, Dir., Ctr. for Drug Evaluation \& Research, to NDA 021071, Decision on Continued Marketing of Rosiglitazone (Avandia, Avandamet, Avandaryl) 2 (Sept. 22, 2010), available at http://www.fda.gov/downloads/Drugs/DrugSafety /PostmarketDrugSafetyInformationforPatientsandProviders/UCM226959.pdf.

251. See GreEN, supra note 83, at 335-39 (noting that false positive findings can produce costs of defense and incorrect verdicts and settlements that are relatively measurable, but social costs associated with incorrect incentive effects are hard to demonstrate and very hard to measure).

252. As shown in Part III.A, to respond with "but if the case is scientifically uncertain then it is not legally proven" is to beg the question. In setting the point at which scientific evidence will satisfy the burden of production, courts choose between the risks of false negative and false positive findings.

253. Gen. Elec. Co. v. Joiner, 522 U.S. 136, 148 (1997) (Breyer, J., concurring).

254. See Green, supra note 18, at 387-88; see also RESTATEMENT (THIRD) OF TORTS: PROD. LiAB. $\$ 15$ (1998) ("Whether a product defect caused harm to persons or property is determined by the prevailing rules and principles governing causation in tort."). 
or a product defect can be proven, however, a false negative causation finding would under-deter conduct that should result in liability. ${ }^{255}$ The Brock court defended its view that in mass tort cases judges should take the causation reins from juries by reference to a well-known passage from Holmes's The Common Law: "But supposing a state of facts is often repeated in practice, is it to be imagined that the court is to go on leaving the standard to the jury forever?" 256 The "standard" referred to is, of course, the standard of conduct, the issue of negligence-a matter of judgment, not purely a question of fact. ${ }^{257}$

A final note on the efficiency rationale is appropriate. Some antitrust scholars have argued that, for certain types of cases, false negative errors are inherently less costly than false positive errors; in time, they say, the market will correct a false negative finding but the inefficiency caused by incorrectly imposing liability may persist indefinitely. ${ }^{258}$ In toxic torts, however, no reason exists to believe this is so. The market mechanism of responsive behavior by competing firms does not exist.

A market response to a false negative causation finding, if possible at all, would have to result from consumers altering their buying behavior to reduce their exposure to the suspected and falsely exculpated product. Conceivably, if ready alternatives for the product exist, manufacturers of the substitutes might turn to marketing strategies exploiting consumer suspicions in an attempt to cash in on a safety premium. ${ }^{259}$ But the marketing machine could also be used to tamp down any consumer concerns about the

255. If no or very little reason exists to believe that a product will cause a particular disease, however, it is difficult to see how a deterrence signal based on false causal ascription could be perceived and acted upon ex ante. After mass exposures, an over-deterrence signal would presumably be perceived from an accumulation of cases in which liability was imposed and the causation findings were false positives.

256. Brock v. Merell Dow Pharms., Inc., 874 F.2d 307, 310 n.8 (5th Cir. 1989).

257. Oliver W. Holmes, JR., The Common Law 123-24 (1881), available at http://www.gutenberg.org/cache/epub/2449/pg2449.html (last visited Jan. 27, 2011).

258. Frank H. Easterbrook, The Limits of Antitrust, 63 Tex. L. REv. 1, 2-3 (1984); Geoffrey A. Manne \& Joshua D. Wright, Innovation and the Limits of Antitrust, 6 J. COMPETITION L. \& ECON. 153, 157 (2010).

259. Denise Grady, In Feast of Data on BPA Plastic, No Final Answer, N.Y. TIMES, Sept. 7, 2010, at D1 (stating that despite lack of clear scientific evidence of harm from plastics containing suspected endocrine disruptor bisphenol-A, consumer fears have improved sales of products advertised as lacking the substance). 
health effects of the now "exonerated" product. ${ }^{260}$ And for many products and exposures, consumer-driven reduction in exposure is simply impracticable. ${ }^{261}$

Perhaps more important, the consequences of a judicial false negative are different in toxic torts than they are in antitrust, both for the losing plaintiff and for society at large. The antitrust plaintiff who wrongly loses suffers unjust pecuniary damages; while the market corrects the anti-competitive behavior, competitors and/or consumers suffer lost welfare, presumably in an amount that decreases over time. The toxic tort plaintiff who wrongly loses has suffered disease and perhaps death, to which the court adds the indignity of no compensation, and often no sense of even being heard. These consequences cannot be corrected, even if the market eventually minimizes or eliminates future exposures.

\section{COMMENT C: RESHAPING TOWARD SYMMETRY}

The Third Restatement does not shy away from the toxic tort causation fray. In comment $\mathrm{c}$ to section 28 , it jumps right in, with forty-one pages of commentary and associated reporters' note. ${ }^{262}$ The treatment of this issue has been called "arguably the single most controversial passage in the project." ${ }^{263}$ Much of the contentiousness arose because comment c acknowledges several of the jurisprudential trends that, together, helped to create the false negative asymmetry. Those who disliked some or all of these trends feared that by recognizing and reporting the law that reflects the trends, the Third Restatement would have the effect of ratifying and reinforcing them. ${ }^{264}$

260. See BRANDT, supra note 232, at 161-63 (describing marketing campaigns aimed at disarming early concerns about the effects of smoking on health).

261. Examples include exposures due to environmental releases (e.g., toxic air emissions, releases to groundwater), exposures requiring product reformulations that manufacturers cannot or will not perform (e.g., benzene in gasoline), current exposures due to past use (e.g., asbestos, lead paint), and unlabeled exposures in consumer products that render consumer choice difficult or impossible (e.g., bisphenol-A in aluminum cans, inert ingredients in household cleaners and other products).

262. Restatement (Third) of TORTs: Liab. For Physical \& EMOtional Harm § $28 \mathrm{cmt}$. c reporters' note $(2010)$. This discussion occupies nearly seven-percent of the text of Volume I of the Third Restatement.

263. Sanders, supra note 20, at 1029.

264. See id. at 1035. Professor Sanders's article on comment c persuasively argues that these trends are real without taking sides on whether they are good or bad developments. 
Given the infrequency and influence of a restatement, there is some basis for this fear, as comment $\mathrm{c}$ accurately describes existing law. ${ }^{265}$ On the other hand, comment $\mathrm{c}$ is no mere recapitulation. Its commentary on the nature of causal proof is potentially subversive because it undermines the claim that courts' de facto preference for false negatives promotes more accurate fact-finding on the toxic tort causation issue.

To understand comment $\mathrm{c}$, it must first be put into context. No black-letter section of the Third Restatement addresses injuries caused by toxic substance exposure as a separate category of tort law in the way, say, that injuries caused by wild animals receive separate treatment. ${ }^{266}$ Comment $c$ elaborates on a provision that simply says the plaintiff has the burden of proving cause-in-fact, which the Third Restatement defines in traditional "but for" terms. ${ }^{267}$ Thus, the Third Restatement treats causation in toxic tort cases as a factually difficult application of a general principle, not as an exceptional category of claim requiring special rules.

This treatment might disappoint those who have argued that the difficulties of proof attending the "special problem" tort causation justify using a causation standard that is in some way less stringent. It also implies, however, that the difficulty of proving toxic tort causation does not justify a more stringent standard: the definition of causation is the same, the burden of persuasion is the same, and the scrutiny of evidence proffered to satisfy the burden should be the same. ${ }^{269}$ Toxic tort causation requires inference from

265. Critics of the trends in toxic tort causation doctrine have also observed these trends; it seems unfair to blame the reporters for reporting them.

266. Restatement (Third) OF Torts: Liab. For Physical \& EMOtional Harm § 22 (2010) (setting forth the rule that owners or possessors of wild animals are strictly liable for physical harm the animals cause).

267. Id. $\S 28(\mathrm{a})$ (plaintiff bears burden of proof); $i d . \S 26$ (defining factual cause in "but for" terms). The Third Restatement acknowledges limited exceptions to each principle. Id. $\S 27$ (stating exception to "but for" causation for multiple sufficient causal sets); $i d$. $\$ 28$ (b) (providing for shifting the burden of proof to the defendant in an alternative liability situation as in Summers v. Tice, 199 P.2d 1 (Cal. 1948)).

268. Id. $\$ 28 \mathrm{cmt} . \mathrm{c}(1)$.

269. Id. $\S 28 \mathrm{cmt} . \mathrm{c}(1)$ at 402 ("In all of these cases, the requirement to prove factual causation remains the same; the plaintiff must prove it by a preponderance of the evidence, and the standards for factual causation set forth in \$\$ 26-27 continue to apply."). The 2002 draft of comment c was less explicit, stating only that "[t] he concept of factual causation remains the same in toxic-substances cases as in other cases, but proof often requires specialized scientific studies." Restatement (ThiRd) of TORTs: Liab. FOR Physical Harm $\$ 28 \mathrm{cmt}$. c(1) (Basic Principles) (Tentative Draft No. 2, 2002). The final language first appeared in the 
circumstantial evidence, but so does any causation finding. ${ }^{270}$ To reach a fact-finder, a plaintiff need do no more than is required in any case: introduce "sufficient evidence to permit a rational factfinder to make a determination that a defendant's tortious conduct was a factual cause of the harm ...."271 True, courts police the evidence to ensure it supports a reasonable inference rather than unwarranted speculation. ${ }^{272}$ But "the line between reasonable inference and prohibited speculation is one of the more indistinct lines that exists in law and also is one on which reasonable minds can and do differ." ${ }^{273}$ From the outset, therefore, the Third Restatement is clear that nothing about black-letter tort doctrine compels the set of rules that courts have established to draw the line between permissible and impermissible evidence of toxic causation.

Despite the reporters' care in situating toxic tort causation as unexceptional, the creation of comment $\mathrm{c}$ involved something quite exceptional. As the reporters explain, "This Comment and these Reporters' Notes benefited significantly from a review of a prior draft by a panel consisting of prominent epidemiologists and a physician ... ," assembled under the auspices of the National Academy of Sciences, which met with the reporters to discuss the issues $^{274}$ in response to objections to an earlier effort. ${ }^{275}$ The reporters would not have needed such assistance for a simple canvass of judicial opinions. Comment $\mathrm{c}$, as approved by the American Law Institute, both describes and assesses the case law. The presence of some normative content in a restatement is perhaps not so extraordinary. What distinguishes comment $\mathrm{c}$ is that it derives its norms primarily from science rather than from legal analysis or a particular philosophy of justice.

\footnotetext{
2003 draft. Restatement (Third) of Torts: Liab. For Physical Harm $§ 28 \mathrm{cmt}$. c(1) (Basic Principles) (Tentative Draft No. 3, 2003). As explained in the text, this presumably pro-defendant amendment (replacing "concept" with "requirement to prove") also serves to emphasize that toxic tort plaintiffs bear no special causation burden. Id.

270. Restatement (Third) of Torts: Liab. For Physical \& EMOtional Harm § $28 \mathrm{cmt}$. b (2010).

271. Id. $\$ 28 \mathrm{cmt}$. a.

272. Id. at cmt. b.

273. Id.

274. Id. $§ 28 \mathrm{cmt}$. c reporters' note.

275. See Discussion of Restatement of the Law Third, Torts: Liability for Physical Harm, 2005 A.L.I. Proc. 33 (2005) (statement of Prof. Green).
} 
In that sense, comment c coheres with the judicial tendency to view toxic tort causation as a purely scientific issue. ${ }^{276}$ Although critics of evolved toxic causation doctrine decry this judicial "abdication," dispassionate scientific advice is a good thing. Justice Breyer-no friend of past toxic tort plaintiffs or current toxic substance regulators-pled for the use of court-appointed scientific experts, not beholden to a party on either side of a legal controversy, to assess causation in toxic tort cases. ${ }^{278}$

Comment $\mathrm{c}$ offers courts the teaching of experts one step further removed, as they considered the issues in general, with no specific party's legal rights riding on the outcome.

\section{A. General Causation and Specific Causation}

As noted above, many courts have treated general causation and specific causation as distinct components of a toxic tort plaintiff's case, each of which must be proven by a preponderance of the evidence-frequently by different types of evidence. Early drafts of comment $\mathrm{c}$ acquiesced in this view. As the 2002 draft put it, "even when general causation is established through the use of group studies, further proof of specific causation is required. Conversely, some evidence of general causation is a prerequisite to proof of specific causation.” ${ }^{279}$ By contrast, the final version states, "specific causation requires attention even when general causation is established through the use of group studies" and "in some cases... the evidence bearing on specific causation may be sufficient to pretermit the need to assess general causation." ${ }^{280}$ The final version also states that exposure, general causation, and specific causation "are not 'elements' of a plaintiff's cause of action ...."

276. See Sanders, supra note 20, at 1041-45.

277. Neil B. Cohen, The Gatekeeping Role in Civil Litigation and the Abdication of Legal Values in Favor of Scientific Values, 33 Seton Hall L. Rev. 943 (2003).

278. Gen. Elec. Co. v. Joiner, 522 U.S. 136, 149-50 (1997) (Breyer, J., concurring).

279. Restatement (Third) Of TORTs: Liab. FOR Physical Harm $\$ 28 \mathrm{cmt} . \mathrm{c}(3)$

(Basic Principles) (Tentative Draft No. 2, 2002) (emphasis added).

280. Restatement (ThiRd) OF TORTS: Liab. FOR PHysical \& EMOTIONAL HARM § $28 \mathrm{cmt}$. c(3) (2010). The "some cases" in which specific causation evidence is unnecessary involve "signature" diseases. Id.

281. Id. $§ 28 \mathrm{cmt} . \mathrm{c}(1)$. 
The distinction between "elements" and "categories for analysis" is "somewhat formalistic." ${ }^{282}$ After all, a plaintiff who cannot prove exposure, general causation, and specific causation usually will lose, and comment $\mathrm{c}$ does not say differently. But the subtle change between Restatement versions is not pure formalism.

To see why, consider two plaintiffs in parallel universes, each of whom advances a claim that ingestion of soma caused them to suffer, after a latency period, the devastating disease somatosis. Assume that causation is the only disputed issue in each case.

In our first parallel universe, the plaintiff proffers a qualified expert witness who reliably testifies that analysis of plaintiff's DNA has revealed DNA-soma addition products ("adducts"), which are consistent with the prevailing scientific model that somatosigenesis begins with DNA alteration. The witness acknowledges that many cases of somatosis occur even in people with no known soma exposure and that not everyone who consumes soma develops somatosis, but states that the plaintiff is not known to have been exposed to any other risk factors and does not appear to have other DNA adducts. The plaintiff in this first alternative universe presents no other evidence on general causation.

In our second parallel universe, the plaintiff proffers a qualified expert witness who reliably testifies that a perfectly conducted epidemiologic study, which sampled two populations absolutely identical in every respect except the consumption of soma, found that the incidence of somatosis is 100 times higher among soma eaters. ${ }^{283}$ The witness acknowledges that many cases of somatosis occur even in people with no known soma exposure and that not everyone who consumes soma develops somatosis. ${ }^{284}$ The plaintiff in this second alternative universe presents no other evidence on specific causation.

If general and specific causation are separate elements of the claim requiring distinct proof, both hypothetical plaintiffs would have to lose without reaching a fact-finder. The first plaintiff's case, supported by specific causation evidence that is about as good as it theoretically gets, would fail for lack of proof of general causation.

282. Sanders, supra note 20, at 1032 .

283. Assume, moreover, that this result is statistically significant at the $99.99 \%$ level and that plaintiff is indistinguishable in any meaningful way from the people studied.

284. To avoid any dose-response issue, assume also that the plaintiff and the soma eaters in the study consumed the same quantity of soma. 
The second plaintiff's case, supported by general causation evidence that is about as good as it theoretically gets, would fail for lack of proof of specific causation. Neither case is airtight. ${ }^{285}$ Yet each presents circumstantial evidence that should be more than enough to get to a fact-finder. ${ }^{286}$

One could question these examples by arguing that really strong group-based evidence amounts to proof of specific causation and really strong particularistic evidence amounts to proof of general causation. But that is exactly why comment c's distinction between "elements" and "organizational categories" is more than formal. These hypotheticals show, and comment c teaches us, that the need for "general" and "specific" causation evidence is a matter of degree, not a matter of doctrinal coherence or scientific accuracy. ${ }^{287}$ In many cases, perhaps in the great majority of cases, courts will draw that line in such a way that both types of proof are required. But the line need not and should not always be drawn this way.

285. It is conceivable that the first plaintiff's somatosis was caused by some undetected factor, and the DNA-soma adducts are not the real cause in this plaintiff, even if they initiate somatosigenesis in others. For the second plaintiff (who more than satisfied the relative risk greater than two threshold, and so would presumably prevail under the articulated law of many jurisdictions), it is conceivable-even with very strong assumptions virtually ruling out sampling error, bias, and confounding - that the association of soma and somatosis is coincidental rather than causal. Epidemiologists would assess that possibility by use of the Bradford Hill criteria, some of which the hypothetical satisfies (e.g., strength of association). None of the Bradford Hill criteria, however, would require particularistic evidence of "specific causation."

286. To test this, one might consider one's own willingness to step into the shoes of each hypothetical plaintiff. On the facts of the first hypothetical, would a reasonable person be willing to have soma adducts formed in his or her DNA in the hope they would not cause somatosis? On the facts of the second, would a reasonable person be willing to consume the relevant amount of soma in the hope the association is coincidental?

287. Comment c arguably limits the severability of general causation and specific causation to cases in which "group-based statistical evidence is proffered." Restatement (Third) OF Torts: Liab. For Physical \& EMOtional Harm § $28 \mathrm{cmt}$. c(1) (2010). By contrast, if "group-based evidence is unavailable or inconclusive, and other forms of evidence are used, the general and specific causation issues may merge into a single inquiry." Id. This does not imply, however, that if epidemiology is unavailable, anything goes; the issues may merge but the plaintiff still must prove causation. 


\section{B. Epidemiologic Evidence and Relative Risk Thresholds}

In comment c's treatment of epidemiology, three features stand out. First, comment $\mathrm{c}$ addresses the two distinct ways in which courts may treat epidemiologic proof as a threshold requirement: whether a showing of causation sufficient to raise a fact issue requires some epidemiologic proof, and whether such a showing requires epidemiologic studies finding a relative risk greater than two. Second, comment c takes a thoroughly pragmatic approach to the use of epidemiology in litigation. Third, comment $\mathrm{c}$ and the associated Reporters' Note effortlessly meld description of how courts have treated epidemiology with prescription of how courts should treat epidemiology.

\section{Is Epidemiology Mandatory?}

Comment c acknowledges that "[o]ccasionally, courts have suggested or implied that a plaintiff cannot meet the burden of production on causation without epidemiologic evidence." ${ }^{288}$ Descriptively, the comment makes the unassailable observation that those court opinions "often" involved situations in which a large body of epidemiologic evidence indicated a lack of association between the agent and the disease. ${ }^{289}$ Prescriptively, the comment states that the requirement of epidemiologic evidence is best limited to similar situations. ${ }^{290}$ The rationale for this judgment is pragmatic: for various reasons, epidemiologic evidence sometimes is simply unavailable. ${ }^{291}$

Contrary to the assertions of some of comment c's critics, the comment does not imply that if no good evidence of causation exists, plaintiffs are free to use bad evidence of causation. ${ }^{292}$ Rather, comment $\mathrm{c}$ adopts the position of " $[\mathrm{m}]$ any courts ... that requiring proof by scientific evidence that does not exist and is not reasonably available to the plaintiff when other, reasonably probative evidence exists is an overbroad method for screening cases." $^{293}$ Just what "other, reasonably probative evidence" might

288. Id. at cmt. c(3).

289. Id.

290. See id.

291. Id.

292. See Discussion of Restatement of the Law Third, Torts: Liability for Physical Harm, supra note 275 (statements of Ms. Bowbeer and Ms. Wells).

293. Restatement (ThiRd) OF TORTS: Liab. FOR PHySiCAL \& EMOTIONAL HARM § $28 \mathrm{cmt}$. c reporters' note (2010) (citing more than two dozen cases). 
be, is a subject on which comment $\mathrm{c}$ is largely silent. ${ }^{294}$ Nonetheless, simply by acknowledging the possibility that general causation can be proven by a preponderance of the evidence without the benefit of studies of the same disease and the same substance at the same exposure level in human beings who are just like the plaintiff, comment $\mathrm{c}$ undermines the claim that the need for accurate fact-finding requires judicial enforcement of the false negative asymmetry.

\section{Must Relative Risk Exceed Two?}

Comment $\mathrm{c}$ acknowledges that as a scientific matter epidemiology cannot and does not investigate causation of individual cases of disease, ${ }^{295}$ but reports and endorses courts' widely (if not universally and sometimes uncomfortably) accepted willingness to infer from group-based causation evidence to individual cases. ${ }^{296}$ From there, it is no great distance for comment c to accept the reasoning that led to the relative risk greater than two rule in the first place: if more than fifty-percent of the disease in an exposed population is attributable to a toxic exposure, then the disease of any exposed individual must, more likely than not, also be attributable to exposure. ${ }^{297}$ Accepting that logic, however, did not lead the reporters to agree to the propriety of the doubled relative risk threshold. Quite the contrary.

294. The reporters describe one exception, a case in which strong circumstantial evidence of specific causation sufficed to establish general causation, where more typical general causation evidence was simply unavailable. Id. at 457 (citing Zuchowicz v. United States, 140 F.3d 381, 385 (2d Cir. 1998)).

295. Id. at 449 .

296. Restatement (Third) of Torts: Liab. For Physical \& EMOtional Harm § $28 \mathrm{cmt}$. c (4).

297. Although widely employed and endorsed by the Third Restatement, this leap is technically incorrect. If a jar contains seventy red jelly beans and thirty green jelly beans, the probability that a randomly-selected jelly bean will be red is seventy percent, but the chosen bean is either red or green-it is not seventy percent likely to be red. The problem in toxic torts, of course, is that except in rare cases it is impossible to see the color of the bean. See generally Wright, supra note 170, at 1311-17 (arguing against interpreting preponderance standard as statistical probability).

298. Restatement (Third) OF TORTS: Liab. For Physical \& EMOTIONAL HARM § $28 \mathrm{cmt}$. c(4) ("[A]ny judicial requirement that plaintiffs must show a threshold increase in risk or a doubling in incidence in a group study in order to satisfy the burden of proof of specific causation is usually inappropriate.”). 
Comment $\mathrm{c}$ recognizes that various factors may affect the persuasiveness of inference from the findings of a group-based study to the assessment of causation in an individual case. ${ }^{299}$ Several of those factors read like the "similarity" requirements imposed by the Texas Supreme Court's decision in Havner: the Third Restatement notes potential differences in degree of exposure to the alleged cause, exposure to other potential causes, and plaintiff's individual risk-conferring characteristics. ${ }^{300}$ But the Restatement's concept of similarity is not so one-sided as Havner's holding that an expert opinion should be excluded if the plaintiff is different from the population in the study on which the opinion is based. A plaintiff whose exposure dose was different from, perhaps less than, the exposure of the study subjects might overcome the difference by evidence of a dose-response relationship. Or a plaintiff might be able to demonstrate individual characteristics that confer not increased risk of disease in general, but increased risk of disease if exposed to the toxic agent in question. $^{301}$

More important, the reporters quote an epidemiology text's acknowledgment that epidemiologists assign the same risk value to all members of a study category simply because measuring the individual risk is impossible. ${ }^{302}$ Comment $\mathrm{c}$ accordingly notes that it may be possible for an individual to produce evidence about his or her individual risk. ${ }^{303}$ If other potential causes of a condition are known, but their applicability can be ruled out in a particular plaintiff's case, this "increases the probability that the agent in

299. Id

300. Id. ("[T]he extent to which the group-study outcome reflects the increased risk to the plaintiff depends on the plaintiff's similarity to those included in the group study.").

301. For example, certain genotypes may confer increased or decreased susceptibility to an exposure's toxic effects. See, e.g., Frederica P. Perera, Molecular Epidemiology: On the Path to Prevention?, 92 J. NAT'L CANCER INST. 602, 604 (2000) (stating that "individual variations in metabolic pathways and DNA repair mechanisms play an important role in breast cancer risk" among women exposed to carcinogens).

302. Restatement (Third) OF Torts: Liab. For Physical \& EMOtional Harm § 28 cmt. c reporters' note (2010) (quoting KenNeTh J. Rothman \& SANDER GreENland, Modern EPIDEMIOLOGy 9 (2d ed. 1998)).

303. Id. $\$ 28 \mathrm{cmt}$. c (2010) (“[C] ourts should permit the parties to attempt to show, based on the sorts of evidence described above [including various factors individual to the plaintiff], whether the plaintiff's disease was more likely than not caused by the agent."). 
question was responsible for that plaintiff's disease." ${ }^{304}$ Increasing the probability of a material fact at issue is, of course, the very definition of relevance. ${ }^{305}$

This understanding explodes several postulates frequently propounded in court opinions that apply the false negative asymmetry. First, it destroys the claim that the "corpuscular" approach to causation evidence, imposing a de facto sufficiency test on each bit of scientific support for an expert's opinion or a plaintiff's allegation of causation, automatically produces more accurate decision making. Second, it necessarily implies that testimony in the nature of differential diagnosis may be probative even if the plaintiff cannot rule out all alternative causes of plaintiff's disease. ${ }^{306}$ Third, it demonstrates that particularistic evidence can and should be allowed to cut both ways, fatally undermining the "benchmark" use of a relative risk exceeding two in cases like Estate of George. ${ }^{307}$

Nothing in these observations about comment $\mathrm{c}$-or in comment c itself-suggests an "anything goes" approach to proof of causation. If a plaintiff's evidence explains away causes that account for only a little disease incidence, the evidence might not be sufficient to push the plaintiff over the preponderance standard. ${ }^{308}$ Moreover, the comment conditions the applicability of individual risk-modifying factors with the proviso, "[s]o long as there is adequate evidence of general causation." comment $\mathrm{c}$ makes no attempt to describe just what that adequate

304. Id

305. See FED. R. EvID. 401 (““[R] elevant evidence’ means evidence having any tendency to make the existence of any fact that is of consequence to the determination of the action more probable or less probable than it would be without the evidence.").

306. Furthermore, it implies exactly the opposite, that even differential diagnoses that can rule out only causes known to account for a small amount of the incidence of disease may be critical, depending on what the other causation evidence shows. As discussed in the next paragraph, to say such evidence is relevant is not to imply that it will always be sufficient.

307. See Restatement (Third) of Torts: Liab. For Physical \& Emotional HARM $\S 28 \mathrm{cmt}$. c reporters' note (2010) (noting that some differences between study population and plaintiff may make study inapposite but others may simply require adjustments when making inferences from group-based study to individual case).

308. See id. ("When the causes of a disease are largely unknown, however, differential etiology is of little assistance."). The combination of a moderately strong epidemiologic association with some ability to rule out alternate causes, however, may provide sufficient evidence.

309. Id. 
evidence might be in all cases. The comment is clear, though, that adequate evidence could be epidemiology with a relative risk less than two, ${ }^{310}$ and persuasively explains why this is so.

\section{The Role of Scientific Judgment and Inference}

Judicial implementation of the false negative asymmetry relies primarily on one or both of two closely-related devices: setting a judicially-defined standard of "good science" that can deliver reliable evidence and confining inference from scientific data to a narrow range of evidentiary "fit." of science that informs comment $\mathrm{c}$ undermines any general claim that these approaches produce more accurate fact-finding.

Although science is brought to bear on claims of toxic causation, scientists themselves informed the reporters that " $[u]$ nfortunately no set formula or algorithm exists for deciding whether a human illness or condition is the consequence of a given exposure to a drug, chemical, or some other agent." ${ }^{312}$ This reality applies broadly to the evidence vel non of toxic causation. ${ }^{313}$

Thus, for example, epidemiologic results require causal interpretation. As comment c notes (but courts seldom do), the need for interpretation works both ways:

Whether an inference of causation based on an association is appropriate is a matter of informed judgment, not scientific methodology, as is a judgment whether a study that finds no association is exonerative or inconclusive.... [One factor to be considered is] an assessment of other scientific evidence that bears on the causal relationship under consideration.... The saliency

310. Id.

311. See, e.g., Gen. Elec. Co. v. Joiner, 522 U.S. 136, 141-46 (1997) (discussing several studies relied on by plaintiff's experts as being too different from plaintiff to support inference of causation); Merrell Dow Pharms., Inc. v. Havner, 953 S.W.2d 706, 721 (Tex. 1997) ("[C] ourts should not foreclose the possibility that advances in science may require reevaluation of what is 'good science' in future cases.").

312. Restatement (Third) Of TORTs: Liab. For Physical \& EMOtional Harm § 28 cmt. c reporters' note (2010) (quoting Jerome P. Kassirer, Joint Discussion of Science, Technology, \& Law Panel \& American Law Institute: Restatement of Torts 12 (Jan. 21, 2003), available at http://sites.nationalacademies.org/PGA/stl /PGA_049555).

313. Restatement (Third) OF TORTs: Liab. For Physical \& EMOtional Harm § $28 \mathrm{cmt}$. c reporters' note (2010) ("This comment could encompass the variety of circumstances that may exist in a toxic-substances case ....”). 
of other evidence of causation often entails considerable judgment. Thus, in some cases, reasonable scientists can come to differing conclusions on whether a body of epidemiologic data justifies an inference of causation. Similarly, reasonable scientists may, in some instances, disagree on whether the absence of an association is exonerative of the agent or is merely inconclusive. ${ }^{314}$

The same conclusion holds for other issues commonly debated in toxic tort causation cases such as evidence of biological plausibility and inference from one biological effect to causation of a related disease. ${ }^{315}$

In the absence of a definitive scientific algorithm for assessing causal claims, where science is genuinely uncertain, reasonable scientists may differ. Courts applying the false negative asymmetry rarely if ever recognize that possibility; instead, the opportunity for reasonable difference is deemed to show that the law must reject a causal claim because science has not yet proven it. ${ }^{316}$ That reasonable scientists may differ does not mean that every difference of opinion between scientists is reasonable. ${ }^{317}$ But by emphasizing the role of judgment in causal attribution, comment $\mathrm{c}$ teaches that

314. Id. § $28 \mathrm{cmt} . \mathrm{c}(2010)$.

315. See id. $\$ 28 \mathrm{cmt}$. c reporters' note (identifying elements in the causal reasoning process for which no scientific algorithm exists). The Restatement acknowledges, albeit in a quite limited way, the possibility that evidence of biological mechanism by which an agent causes one disease could permit an inference that the agent causes a related disease. Id. at 446. Courts should consider whether the known or suspected biological mechanism supports reasonable analogy and whether fine subdivisions in disease-type classifications reasonably reflect variation in the underlying biological mechanism. Compare, e.g., Casdorph v. W.Va. Office Ins. Comm'r, 690 S.E.2d 102 (W. Va. 2009) (affirming worker's compensation award where claimant's expert inferred causal link between benzene and one type of leukemia based on evidence that benzene causes another type of leukemia), with Milward v. Acuity Specialty Prods. Group, Inc., 664 F. Supp. 2d 137 (D. Mass. 2009) (excluding plaintiff's expert testimony because defense experts testified that benzene caused leukemia by damaging chromosomes in a specific way not observed in plaintiff's type of leukemia), rev'd, No. 09-2270, 2011 WL 982385 (1st Cir. Mar. 22, 2011). For discussion of the First Circuit's opinion in Milward, see infra Part IV.D.2.

316. See Joiner, 522 U.S. at 145 (reasoning that if a study's authors declined to infer a causal relationship, the study could not support an expert's conclusion of causation).

317. Thus, this discussion does not imply that every plaintiff's expert should be allowed to testify and that every plaintiff's case supported by an expert should reach a jury. Certainly comment $c$ makes no such claim. The reporter's note to comment c offers express approval to numerous cases in which plaintiffs' evidence was held inadmissible or insufficient. See, e.g., Restatement (ThIRD) OF TORTs: Liab. FOR PhysicAl \& EMOTIONAL HARM $\S 28$ cmt. c reporters' note (2010). 
judicial hostility to the application of judgment and inference in support of causal claims does not necessarily provide legal answers that are more scientifically accurate. Where reasonable scientists can differ, neither truth-seeking nor the allocation of the burden of proof compels the false negative asymmetry.

Comment $\mathrm{c}$ notes that outside the courtroom, scientists might apply quite a different asymmetry:

Scientists' judgments about causation outside the legal context may also be affected by the comparative costs of errors, as when caution counsels in favor of declaring an uncertain agent toxic because the potential harm it may cause if toxic is so much greater than the benefit forgone if it were not introduced.

This is a fair paraphrase of the precautionary principle frequently advocated as an appropriate basis for environmental regulation. ${ }^{319}$ Whatever its virtues and faults, the precautionary principle certainly does not describe how our society actually treats the introduction and use of potentially toxic substances. Despite a huge amount of scientific effort, we have little to no firm knowledge of the toxicology of most substances. ${ }^{320}$ In the one area where we attempt a version of the precautionary principle, approval of drugs, unexpected harms nevertheless regularly become apparent after approval. ${ }^{321}$

Tort law also is not premised on the precautionary principle, ${ }^{322}$ and in 2005, the reporters had to assure the American Law Institute that comment $\mathrm{c}$ was not intended to embrace a regulatory precautionary principle in a torts context. ${ }^{323}$ Still, by showing that reasonable scientists may differ-an acknowledgment almost never seen in the "truth-seeking" case law-comment c provides courts

318. Id. $\$ 28 \mathrm{cmt} . \mathrm{c}$.

319. See Robert V. Percival, Who's Afraid of the Precautionary Principle?, 23 PACE ENVTL. L. REV. 21, 23-27 (Winter 2005-2006) (describing history of various articulations of precautionary principle).

320. Albert C. Lin, Beyond Tort: Compensating Victims of Environmental Toxic Injury, 78 S. CAL. L. REV. 1439, 1447-48 (2005) ("Reliable information regarding carcinogenic and other health effects is available for relatively few substances. For many substances, health effects are unknown.").

321. See supra notes 208-13 and accompanying text.

322. See Tamraz v. Lincoln Elec. Co., 620 F.3d 665, 673 (6th Cir. 2010) (contrasting physician's use of precautionary principle to advise patient to avoid suspected cause of disease with judicial preponderance standard).

323. See Restatement (Third) Torts: Liab. For Physical \& Emotional Harm § 28 (Proposed Final Draft No. 1 2005). 
with a way to apply a scientifically legitimate but flexible approach to toxic tort causation.

\section{Comment $c$ and the Courts}

Comment c provides a convincing rationale for reshaping toxic tort causation requirements toward symmetry. Whether courts will take that path remains to be seen. As of this writing, only two reported decisions have discussed comment $\mathrm{c}$ in a substantive way. ${ }^{324}$

\section{Ranes v. Adams Laboratories, Inc.}

In Ranes v. Adams Laboratories, Inc., ${ }^{325}$ the Iowa Supreme Court affirmed a trial court's exclusion of plaintiff's expert causation testimony and the ensuing summary judgment for defendants. ${ }^{326}$ Considering how unfavorable the plaintiff's facts were, it is a surprisingly subtle opinion.

Mr. Ranes alleged that a few doses of cold medicine containing phenylpropanolamine (PPA) had caused a broad range of symptoms, including widely dispersed pain and numbness, that continued and became more severe long after he stopped taking the medicine. ${ }^{327}$ The plaintiff's expert witness, a toxicologist who had reviewed plaintiff's medical records but never examined him, concluded that the plaintiff suffered from cerebral vasculitis or a stroke. $^{328}$ Relying on case reports and an epidemiologic study that found increased risk of stroke in women (but not men) who had consumed PPA-containing pills for weight loss, ${ }^{329}$ the expert was prepared to testify that PPA had caused plaintiff's progressive neurologic symptoms. ${ }^{330}$ The court's lengthy factual recitation took care to note that the plaintiff sought medical treatment for these symptoms before consuming the PPA and that numerous treating neurologists and imaging technologies failed to find any objective

324. A LEXIS search conducted on September 20, 2010 found only three federal or state court opinions citing comment $\mathrm{c}$ in any way, including (search terms and result on file with author). As this article was in the final stages of preparation for publication, one additional court opinion citing comment $\mathrm{c}$ was issued. See infra Part IV.D.2.

325. 778 N.W.2d 677 (Iowa 2010).

326. Id. at 697.

327. Id. at 682-83.

328. Id. at 684 .

329. Id. at 692.

330. Id. at 684 . 
evidence of stroke or vasculitis. ${ }^{331}$

Before Ranes, Iowa had rejected the Frye general acceptance test but also declined wholesale adoption of Daubert, "suggesting" that courts consider the Daubert factors with respect to "particularly novel or complex" scientific evidence. ${ }^{332}$ Although trial judges in Iowa must assess expert testimony for reliability and relevance before admitting it, Iowa uses an "ad hoc approach" 333 to determining scientific reliability. "Generally," the Iowa Supreme Court has "been committed to a liberal view on the admissibility of expert testimony." ${ }^{334}$ Ranes, however, pushed the court too far.

As a result, the court embraced a form of toxic tort exceptionalism that is something of a hallmark of the false negative asymmetry. Noting that "we encourage a more expansive judicial gatekeeping function in difficult scientific cases" $" 335$ and that Daubert itself was a toxic tort case, the court endorsed use of the Daubert factors-as well as federal case law interpreting Daubert-in toxic tort cases. ${ }^{336}$ The court rejected plaintiff's expert's reliance on the epidemiologic study linking PPA to stroke because no evidence suggested plaintiff had suffered a stroke. ${ }^{337}$ The court rejected the expert's reliance on case reports partly because of the limited utility of such evidence but principally because the symptoms in the case reports differed significantly from plaintiff's symptoms. ${ }^{338}$

Despite these wholly appropriate rulings, the Ranes court took some care to avoid creating rigid rules for causation proof. The court emphasized that it was not demanding scientific certainty ${ }^{339}$

331. Id. at $682-84$.

332. Id. at 686 .

333. Id.

334. Id. at 685. Even in Ranes, the Iowa Supreme Court emphasized repeatedly that scrutiny of expert opinions should be based on methodology, not conclusions. Id. at 691. The court expressly rejected the holding from Kumho Tire Co. v. Carmichael, 526 U.S. 137 (1999), extending Daubert beyond scientific testimony to "technical or other specialized knowledge." Id. at 686.

335. Id. at 686 .

336. Id. at 687 .

337. Id. at 692 ("All eight neurologists involved with Ranes' case refuted the diagnosis of stroke. . . . [T] his case-control study is not relevant to the injuries alleged in this case and cannot be the basis of any general causation opinion.").

338. Id. at 694 (noting that plaintiff's expert relied on clinical experience in which PPA caused symptoms that disappeared after administration of PPA ceased, unlike plaintiff whose symptoms continued to worsen; expert testified that "no existing case reports" showed plaintiff's symptomology).

339. Id. at 688 ("[P]laintiff's expert must only be qualified to offer a theory of causation for the jury's consideration, not absolute certainty. There must be evidence that would permit a reasonable person to conclude the drug probably 
and stated that epidemiologic proof is not required, citing with approval a federal case in which expert testimony based on "case reports in addition to other facts" was admitted. ${ }^{340}$ In rejecting plaintiff's expert's reliance on dissimilar case reports, the court noted the lack of "facts or circumstances to support the analogy"; presumably in another case where such "circumstances" were shown, the testimony would more likely be admitted. ${ }^{341}$ The flexibility reflected in these statements is fully consistent with the thrust of comment $\mathrm{c}$.

Ranes expressly invoked comment $\mathrm{c}$ in discussing general causation and specific causation, a "bifurcated analysis" that previously had "not been explicitly used as the standard in Iowa." 342 The court observed that comment c "recognized this relatively recent common practice as a 'device[] to organize a court's analysis' and not as additional elements of the tort," and quoted the Restatement's analysis at some length. ${ }^{343}$ Ranes concluded that "it is appropriate for courts to use the bifurcated causation language in toxic-tort cases," but went on to say that "both types of causation must be proven." ${ }^{344}$ The causation evidence in Ranes was so poor that it remains unclear whether Iowa will treat general causation and specific causation in the manner suggested by comment $\mathrm{c}$ or more like "elements" of a claim-each requiring separate proof.

Ranes illustrates the principle that bad toxic tort claims make hard toxic tort causation rules that may later be applied to dismiss better but uncertain claims. What Ranes most has in common with the cases that created the false negative asymmetry is a reticence to apply a judicial version of Occam's razor by deciding cases on the narrowest ground possible. The plaintiff's causation theory rested entirely on the diagnosis that plaintiff "suffered from the effects of vasculitis." "345 The Iowa Supreme Court held that plaintiff's expert's diagnosis was unreliable ${ }^{346}$ and the expert, as a toxicologist, was not

caused the injury claimed.”).

340. Id. at 693 (citing Bonner v. ISP Techs., Inc., 259 F.3d 924, 929-31 (8th Cir. 2001)).

341. Id. at 694 .

342. Id. at 688 .

343. Id. (quoting Restatement (Third) of TORTS: Liab. FOR Physical \& EMOTIONAL HARM $§ 28 \mathrm{cmt}$. c (2010)).

344. Id. at 688 (emphasis added).

345. Id. at 695 .

346. Id. at 696-97 (noting, for example, that although plaintiff's expert purported to conduct a differential diagnosis to determine that plaintiff had vasculitis, the expert "summarily dismissed as many as eight mimicking conditions 
even qualified to give an expert opinion on such a complex neurological diagnosis. ${ }^{347}$ To dispose of the case, no more was required. Yet Iowa now has an opinion of its supreme court that seems to stand for aspects of the false negative asymmetry, and that justifies its result, once again, by concluding that "[l]aw lags science." ${ }^{348}$

\section{Milward v. Acuity Specialty Products Group, Inc.}

As this article was going to press, the United States Court of Appeals for the First Circuit issued its opinion in Milward v. Acuity Specialty Products Group, Inc., ${ }^{349}$ reversing the district court's exclusion of plaintiffs' expert on general causation.

The scenario Milward presented to the court was the antithesis of Ranes in almost every way. Mr. Milward's alleged exposure-to benzene-was lengthy and occupational. ${ }^{350}$ His diagnosed illnessacute promyelocytic leukemia (APL)—was severe and uncontested. $^{351}$ And his expert witness-Dr. Martyn Smith-was "acknowledged as a leading expert" on the study of benzene toxicity and the causes of leukemia and lymphoma.

Dr. Smith invoked a "weight of the evidence" methodology in concluding that at least four pieces of circumstantial evidence, taken together, supported an inference of causation. ${ }^{353}$ The district

due to his lack of background and experience in diagnosing neurological diseases").

347. Id. at 695 ("[N]o evidence was offered to reveal sufficient experience, knowledge, or training to show [plaintiff's expert] was qualified to render such a complex diagnosis.").

348. Id. at 697 (quoting Rosen v. Ciba-Geigy Corp., 78 F.3d 316, 319 (7th Cir. 1996)).

349. No. 09-2270, 2011 WL 982385 (1st Cir. Mar. 22, 2011).

350. Id. at $* 1$.

351. Id.

352. Id. at *3. The court of appeals (but not the district court) noted that at the Daubert hearing, plaintiffs also introduced testimony by Dr. Carl Cranor, a philosopher of science. Id. at $* 1$.

353. Milward v. Acuity Specialty Prods. Grp., 664 F. Supp.2d 137, 143-44 (D. Mass. 2009), rev'd, No. 09-2270, 2011 WL 982385 (1st Cir. Mar. 22, 2011). The four bases of the expert's opinion were: (1) benzene is known to cause other subtypes of acute myelogenous leukemia (AML), with which the APL sub-type has enough in common to infer a common pathogenesis; (2) APL is characterized by breakage and rearrangement of a particular chromosome, and benzene is known to have the ability to break chromosomes; (3) benzene metabolites are known to inhibit an enzyme that protects chromosomes from damage, and chemicals that inhibit the same enzyme are known to cause various sub-types of AML; and (4) limited epidemiologic study shows an increased risk of APL associated with 
court examined each piece of support individually and concluded that each failed Daubert's reliability prong because the validity of inferring causation from each of them remained in doubt. ${ }^{354}$ The First Circuit rejected this "atomistic[]" approach ${ }^{355}$ and held that a jury should decide whether or not to accept the expert's conclusion. $^{356}$

Four features of the First Circuit's opinion stand out. For each of these salient points, the court expressly drew significant support from comment c.

First, the court of appeals issued the strongest and most explicit judicial endorsement to date of a weight of the evidence methodology for proof of causation in a toxic tort case. In contrast to courts that have treated the absence of quantitative weighting factors as an absence of scientific rigor, ${ }^{357}$ the First Circuit agreed with the plaintiffs that "weight of the evidence" is not standardless mush but a methodology that scientists may legitimately use for assessing causation. ${ }^{358}$ In doing so, the court relied in part on the Third Restatement's observation that “[n]o algorithm exists for applying the [Bradford] Hill guidelines to determine whether an association truly reflects a causal relationship or is spurious." ${ }^{, 359}$

Second, the court of appeals accepted without discussion the implicit premise of Dr. Smith's testimony that the existence of some of the Bradford Hill factors could support a causation inference even in the absence of a statistically significant association found by epidemiology, ${ }^{360}$ a premise some other courts

occupational exposure to benzene, although the results are not statistically significant. Id.

354. Id. at 144-49. The technique, of course, is similar to the Supreme Court majority's approach in Joiner. See supra notes 214-218 and accompanying text.

355. Milward, 2011 WL 982385, at*9.

356. Id. at $* 1$.

357. Estate of George v. Vt. League of Cities \& Towns, 993 A.2d 367, 379 (Vt. 2010).

358. Milward, 2011 WL 982385, at *5; see id. at n.9 (treating as limited to its facts Allen v. Pa. Eng'g Corp., 102 F.3d 194, 198 (5th Cir. 1996), which stated that weight of the evidence approach was appropriate for the lower threshold of proof for regulatory agencies implementing a "preventive perspective").

359. Id. at *9 (quoting Restatement (THIRD) OF TORTS: Liab. FOR PHySiCAL \& EMOTIONAL HARM $\S 28 \mathrm{cmt}$. c(3)). For discussion of the Bradford Hill guidelines, see also Green, supra note 64, at 375-79.

360. Milward, 2011 WL 982385, at*4 (explaining expert's use of Bradford Hill guidelines); $i d$. at $* 11$ (noting that epidemiologic studies "do not offer conclusive statistically significant evidence either way"). The district court was similarly silent. See Milward, 664 F. Supp. 2d at 142-43 (describing Dr. Smith's opinion without mentioning Bradford Hill guidelines). The defendants' appellate brief repeatedly 
have rejected. ${ }^{361}$ This premise is consistent with the decision's overall approach to epidemiology. The district court acknowledged that epidemiology "is not always essential" but agreed with the defendants that "epidemiological studies are ordinarily needed." ${ }^{362}$ The court of appeals opined that the trial judge "read too much into the paucity of statistically significant epidemiological studies." ${ }^{\text {"363 }}$ Distinguishing this case from situations in which numerous powerful epidemiologic studies found no association, the First Circuit noted not only the small number of epidemiologic studies of benzene and APL but also the inherently limited power of those studies. ${ }^{364}$ In such circumstances, the little epidemiologic evidence that exists becomes a subsidiary consideration that may or may not tend to confirm other bases for the causal inference, rather than the other way around. ${ }^{365}$

The First Circuit held that the jury should evaluate the parties' experts' conflicting views of the meaning of the epidemiologic evidence. $^{366}$ That holding is consistent with comment c's explanation that "other, reasonably probative evidence" could suffice in the absence of epidemiologic results that are practically unobtainable. ${ }^{367}$

referred to the absence of epidemiologic support for Dr. Smith's conclusion but barely mentioned it in connection with the Bradford Hill guidelines. See Brief for Defendants-Appellees at 38 n.18, Milward v. Acuity Specialty Prods. Grp., No. 092270, 2011 WL 982385 (1st Cir. Mar. 22, 2011).

361. E.g., Dunn v. Sandoz Pharm. Corp., 275 F. Supp. 2d 672, 678-79 (M.D.N.C. 2003).

362. Milward, 664 F. Supp. 2d at 148.

363. Milward, 2011 WL 982385, at *11 (citing RESTATEMENT (THIRD) OF TORTS: LiAB. FOR PHYSICAL \& EMOTIONAL HARM $\$ 28$ cmt. c(3) reporters' note (2010)).

364. Milward, 2011 WL 982385, at*11 (stating that "the few studies . . do not offer conclusive statistically significant evidence either way, in part because the rarity of APL makes it nearly impossible to perform a large enough study"). According to apparently undisputed facts recited in both the Milward opinions, the incidence of APL is in the range of 2 to 8 cases per million people. Id. at $* 4$ (stating AML incidence is 3.5 cases per 100,000, of which five to ten percent are APL); Milward, 664. F. Supp. 2d at 143 (giving AML incidence as six to eight cases per 100,000, of which five to ten percent are APL).

365. Milward, 2011 WL 982385, at*11 (noting that plaintiffs' expert testified "that the limited epidemiological evidence was at the very least consistent with, and suggestive of, the conclusion that benzene can cause APL" but "did not infer causality from this suggestion alone").

366. Id. at $* 10$.

367. Restatement (ThiRd) OF TORTS: Liab. FOr Physical \& EMOtional Harm § 28 cmt. c (2010). 
Third, the court of appeals fully embraced comment c's teaching that the scientific method and the exercise of judgment are not incompatible and are actually inseparable. ${ }^{368}$ Defendants argued that only personal beliefs underlay the plaintiffs' expert's "weight of the evidence" conclusion. ${ }^{369}$ The court did not agree, finding that the weight of the evidence approach made the role of judgment "more readily apparent" but that judgment and interpretation are required regardless of the methodology used to evaluate causation. ${ }^{370}$ The opinion correctly notes that quantitative results and statistical significance testing, as are found in epidemiologic studies, do not eliminate the need for the exercise of scientific judgment. ${ }^{371}$

Fourth, the court of appeals emphasized, as comment $\mathrm{c}$ emphasized, that a reasonable difference of scientific opinion does not render a causation expert's testimony inadmissible. ${ }^{372}$ The court noted that the defendants' experts, though they disagreed with the plaintiffs' expert's conclusion, acknowledged that reasonable scientists agreed with important parts of the basis of that conclusion. ${ }^{373}$ For example, plaintiffs' expert testified that a feature common to the genesis of APL and other AML sub-types supported the inference that all shared a common etiology. ${ }^{374}$ The defendants' experts, by contrast, emphasized the many ways in which APL is different from other sub-types of AML. ${ }^{375}$ The dispute was not over whether these differences exist, but about whether they are important to the validity of the inference. The First Circuit appropriately held that deciding that dispute entailed weighing the

368. Id. at *5 (quoting Restatement (THIRD) OF TORTS: Liab. FOR PHySiCAL \& EMOTIONAL HARM $§ 28 \mathrm{cmt}$. c(3), c (4)).

369. See, e.g., Brief for Defendants-Appellees at 66, Milward v. Acuity Specialty Prods. Grp., No. 09-2270, 2011 WL 982385 (1st Cir. Mar. 22, 2011) (characterizing weight of the evidence approach as "based solely on subjective and undisclosed personal views").

370. Milward, 2011 WL 982385, at *5 (quoting RESTATEMENT (THIRD) OF TORTS: Liab. FOR PHYSICAL \& EMOTIONAL HARM $\$ 28$ cmt. c(1) (2010)).

371. Id. at *5 n.8 (quoting Restatement (THIRD) OF TORTS: LIAB. FOR PHYSICAL \& EMOTIONAL HARM $\$ 28 \mathrm{cmt}$. c(3) (2010).

372. Id. at *5 (quoting Restatement (Third) OF TORTs: Liab. For Physical \& EMOTIONAL HARM $\$ 28 \mathrm{cmt}$. c(4) reporters' note (2010)).

373. Id. at *6 nn.10, 11 .

374. Id. at *6; see also supra note 354 .

375. See, e.g., Brief for Defendants-Appellees at 61, Milward v. Acuity Specialty Prods. Grp., 664 F. Supp.2d 137, 143-44 (D. Mass. 2009), No. 09-2270 (characterizing weight of the evidence approach as "based solely on subjective and undisclosed personal views"). 
evidence rather than assessing its reliability. ${ }^{376}$

This last aspect of Milward offers the greatest promise of reshaping toxic tort causation law toward symmetrical treatment of potential errors. Guided in part by comment c, the First Circuit refused to denigrate causation evidence merely because the evidence required inference, incremental assembly, and reliance on scientific evidence that may not satisfy a judicially-crafted ideal.

The district court had rejected as unreliable the various building blocks of plaintiffs' expert's conclusion, not because they had been proven wrong but because they were debatable. The validity of reasoning that benzene can cause APL by analogy to other sub-types of AML, for instance, depended in part on the stage of cellular maturation at which a developing blood cell becomes leukemic: transformation at an early stage would tend to support plaintiffs' expert's inference, while transformation only at a later stage would tend to negate it. ${ }^{377}$ The district court, quoting a published paper for the proposition that in APL the transformation "may occur" at a later stage, ${ }^{378}$ concluded that the scientific answer to this question remains elusive and therefore the proffered testimony must be excluded. ${ }^{379}$

The court of appeals, by contrast, confronted with a record demonstrating that the issue is "currently the focus of extensive scientific research and debate and on which reasonable scientists can clearly disagree," held that the appropriate conclusion was not to deem the plaintiffs' evidence unreliable but to send the dispute to a jury. ${ }^{380}$ For purposes of evaluating expert testimony, the court held, "[1]ack of certainty is not . . . the same thing as guesswork." The court did not relieve the plaintiffs of their burden of proving

376. Milward, 2011 WL 982385, at $* 9$.

377. Milward, 664 F. Supp. 2d at 144-45.

378. Id. at 145 .

379. Id. at 146. Similarly, the district court rejected as unreliable two other pieces of indirect evidence. The court rejected the reasoning that because benzene is known to cause some chromosome breaks, it could cause the chromosome break usually seen in APL, absent "direct observational evidence" of the latter effect. Id. at 147. The court also held inapplicable the fact that benzene metabolites are known to inhibit an enzyme, the inhibition of which by other chemicals is known to produce other AML sub-types, based on an article concluding that the precise mechanism by which benzene causes leukemia cannot, at this time, be "confidently identif[ied]." Id. at 148.

380. Milward, 2011 WL 982385, at*9.

381. Id. at *8 (quoting Primiano v. Cook, No. 06-15563, 2010 WL 1660303, at *5 (9th Cir. Apr. 27, 2010)). 
causation by a preponderance of the evidence - but it also did not impose on plaintiffs the entire burden of scientific uncertainty. ${ }^{382}$

Whether other courts will follow Milward and its application of comment $\mathrm{c}$ remains to be seen. And of course Milward does not, as it could not, overrule the Daubert trilogy. Even in the First Circuit, a plaintiff who overplays a Milward hand will likely lose a Daubert challenge: procuring an expert willing to incant "weight of the evidence" will not provide an automatic ticket to a jury. But by the same token, a defense expert who fastidiously avoids an honest confession that "reasonable scientists may disagree" will not thereby ensure automatic exclusion of the plaintiff's expert. District judges hearing toxic tort cases in the First Circuit still wield the discretion of gatekeepers. Milward instructs them to be on the lookout for disputes marked by scientific uncertainty and reasonable scientific disagreement, without providing much guidance about how to know when they have found one. But Milward at least tells district judges, quite clearly, that when they do find one, their rulings should not be distorted by the false negative asymmetry.

\section{CONCLUSION}

The trajectory of toxic tort litigation induced many courts to elaborate rules for proof of causation that, collectively, created the false negative asymmetry. The science rationale, the legitimacy rationale, and the welfare rationale do not provide adequate justification for the general application of the false negative asymmetry. Commingled with all these rationales is the claim that the rules comprising the false negative asymmetry promote superior truth-seeking. The commentary on toxic causation in the Third Restatement undermines this claim. As courts continue to decide toxic tort causation controversies, they undoubtedly will look to comment $\mathrm{c}$ for guidance. They will be able to find in it, as in any text, a variety of meanings. Yet if courts take care to learn fully the teaching of comment $\mathrm{c}$, they will find not just a restatement of what courts have done but an opportunity to reshape what they will do, for the better.

382. Id. at *1. 